Document downloaded from:

http://hdl.handle.net/10251/60350

This paper must be cited as:

Gasch Molina, MI.; Alvarado Vargas, YA.; Calderón García, PA. (2012). Temperature effects on load transmission between slabs and shores. Engineering Structures. 39:89-102. doi:10.1016/j.engstruct.2012.02.004.

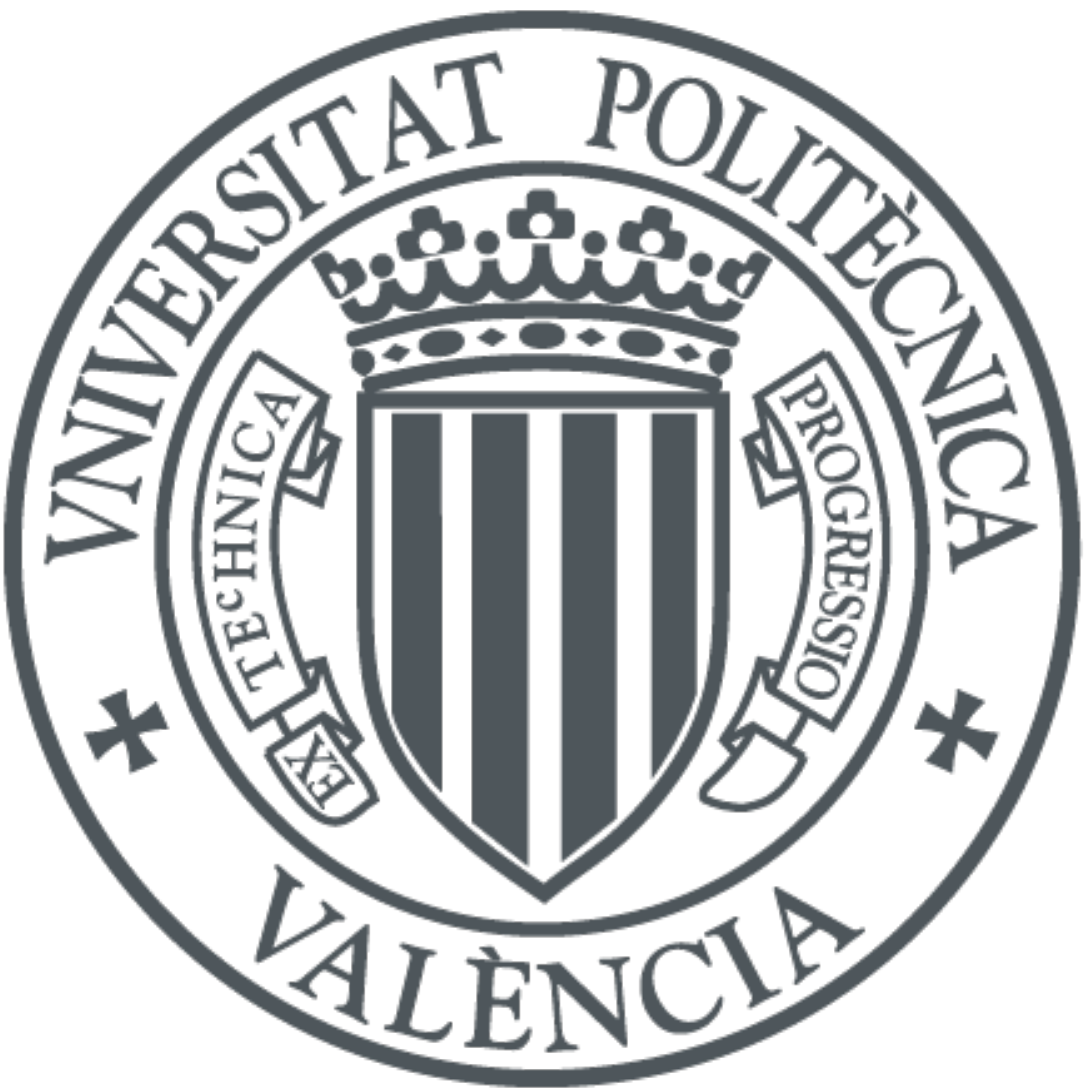

The final publication is available at

http://dx.doi.org/10.1016/j.engstruct.2012.02.004

Copyright Elsevier

Additional Information 


\title{
Temperature effects on load transmission between slabs and
}

\author{
shores. \\ Isabel Gasch, Yezid A. Alvarado ${ }^{1}$, Pedro A. Calderón \\ ICITECH, Universidad Politécnica de Valencia. Camino de Vera s/n, 46022 Valencia, Spain
}

\begin{abstract}
This paper analyses the influence of temperature changes on load transmission between floor slabs and shores during the in situ casting of concrete slabs by the shoring-clearing-striking method. Therefore several experimental studies were carried out which measured both the internal temperature evolution of the slabs and the loads on the shores. With the results of these studies, a Finite Element Model (FEM) of an experimental structure was then developed. In both the FEM and the experimental studies the same behaviour was observed regarding changes in temperature. When temperatures rose, the loads on shores decreased, accompanied by a reduction in slab deflection. When temperatures dropped, the loads on the shores increased, accompanied by an increased slab deflection. In the experimental study, for a temperature increment of $\pm 1^{\circ} \mathrm{C}$ the load per surface unit on shores varied between $0.13 \mathrm{kN} / \mathrm{m}^{2}$ and 0.34 $\mathrm{kN} / \mathrm{m}^{2}$, which represents between $2 \%$ and $6 \%$ of the self-weight of the slabs. The main cause of these load variations appears to be the temperature gradient inside the floor slabs.
\end{abstract}

Keywords: shoring; finite element modelling; partial striking; formwork; concrete construction; temperature of concrete; construction process.

\section{Introduction}

In most building works in which floor slabs are laid in situ, the shoring and striking of successive floors is the most often used method. The speeding up of construction times and the reduction of costs are

\footnotetext{
${ }^{1}$ Corresponding author. Tel.: +34 963877007 ext. 75619; fax: +34 963877569.

E-mail address: yealvar@upvnet.upv.es (Y.A. Alvarado).
} 
mainly based on making available for re-use, as soon as possible, all or most of the components used in the process. The striking time depends on many factors, especially on the building system used, the characteristics of the work itself (type of concrete and loads) and even on the atmospheric temperature and humidity while the work is being carried out. In all cases, financial factors are subject to structural safety criteria, as a considerable number of building collapses take place during the construction process [1-3].

In Spain, a technique known as clearing or partial striking is used to improve construction times and reduce costs without compromising structural safety. It consists of reducing the number of support components by removing, some days after pouring, the formwork and over $50 \%$ of the shores that support the floor slabs, while ensuring that the remaining shores stay in contact with the structure. To date, few authors have studied the clearing technique, and only Moragues et al. [4] and Alvarado et al. [5,6] have carried out experimental and theoretical studies on its application. Other theoretical and experimental studies on load transmission between shores and slabs have not taken the clearing technique into consideration. For example, one of the currently most used methods to measure loads on shores and slabs is Grundy \& Kabaila's (1963) simplified method [7], which is easy to apply and in most cases errs on the side of safety. However, later studies by other authors such as Liu et al. [8], Stivaros \& Halvorsen [9], Chen Mosallam [10], Duan \& Chen [11], Moragues et al. [4], Fang et al. [12], Beeby [13] and Alvarado et al. [5] agree that Grundy \& Kabaila's simplified method [7] overestimates the loads on shoring, mainly due to the fact that the latter authors consider shores to be infinitely stiff. This factor is crucial in considering the effects of clearing, as pointed out by Alvarado et al. [6] , Alvarado [14] and Calderón et al. [15].

Another factor that has received little attention to date is the effect of ambient temperature changes on load distribution between shores and floor slabs, even though certain authors have emphasized its importance. Rosowsky et al. [16] measured the evolution of the loads on shores for a number of days after pouring and obtained daily cyclical fluctuations which they attributed to environmental changes at the site. They also observed a tendency for loads to decrease during the slab curing process. Fang et al. [17] also measured the loads on shores during slab curing. In agreement with Rosowsky et al. [16], they established that the load evolution on slabs is influenced by daily temperature variations and also detected a reduction of loads during the curing process. Fang et al. [18] subsequently carried out an analytic study 
to determine the influence of temperature (and other variables) on the re-distribution of the loads on slabs. They concluded that variations in ambient temperature cause loads on slabs to fluctuate increasing the maximum load.

The present study analyses the effect of temperature on the load distribution on shores, for which the results of an experimental building studied by Alvarado et al. [5], built according to the shoring-clearingstriking process, are used. In his experiment work, Alvarado [14] detected the importance of ambient temperature variations on shore loads during the building process. Such temperature changes affect all the structural elements during construction (slabs, columns, shores, formwork boards, straining pieces) and they induce strong load variations on shores and floor slabs. In order to determine the principal causes of these load variations, different building sites were monitored during construction in order to observe the temperature gradients inside reinforced concrete slabs during variations in the ambient temperature. The results have been used to determine the influence of temperature changes on load variations on shores by developing a theoretical finite element model. The FE model developed by Alvarado et al [6] was used to simulate the building while introducing the temperature changes that occurred in the different structural elements during the construction process. The results from the model were compared with the load measurements obtained from the shores in the experimental building to verify that this building correctly reproduced the appropriate behaviour patterns.

\section{Experimental study}

For the experimental study, the building described by Alvarado et al [5] and Alvarado [14], in Valencia, Spain, was used, as well as two other buildings, in which temperature evolution was measured in the interior of the floor slabs. These other buildings were situated in Valencia (at a short distance from the experimental building) and Sabadell, Spain, (with a climate very similar to Valencia).

\subsection{Description of the experimental building}

For the experimental study, a full scale three-storey building structure was constructed in the grounds of the ICITECH laboratory at the Polytechnic University of Valencia. The floor slabs consisted of reinforced concrete $0.25 \mathrm{~m}$ thick in all storeys, with a height between floors of $2.75 \mathrm{~m}$. The slabs were supported by four rectangular columns at $6.00 \mathrm{~m}$ from each other and had a cantilever of $1.80 \mathrm{~m}$. The 
concrete used for all the structural elements of the building had a characteristic 28 day compressive strength of $25 \mathrm{MPa}$. A view of the experimental building can be seen in Figure 1.

The construction process of each floor slab consisted of shoring, clearing and striking. In order to simulate the construction of a fourth floor, a uniformly distributed load consisting of plastic containers filled with water was applied to the third floor. A total of 80 shores were used, on each of which three strain gauges were placed at a height of $1.25 \mathrm{~m}$ at an angle of $120^{\circ}$. The load to which each of the shores was subjected was calculated from the average deformation value of the three gauges. Three shores were used to measure the effect of ambient temperature on shores, strain gauges and data acquisition hardware. These shores were not subjected to loads and thus did not form part of the building support. Five LVDTs were also applied to each of the slabs to measure deformation during the building process. The arrangement of the shores and the strain gauges can be seen in Figure 2. To measure temperature evolution, three thermocouples were embedded in each slab to record the interior temperature (see arrangement in Fig.2). Two thermocouples were also fixed to the surface of two shores, and two others were used to record ambient temperatures. Two PCs with software developed by ICITECH personnel were used for data handling and were installed in an adjacent building. For a detailed description of the experimental study, see Alvarado et al [5] and Alvarado [14].

\subsection{Description of the Sabadell building}

A building with 2 basement levels and 5 above ground storeys located in Sabadell, Barcelona, was monitored during its construction. All the floors are made of $0.32 \mathrm{~m}$ thick $(0.25+0.07)$ cast-in-place girderless hollow floor slab, with $0.15 \mathrm{~m}$ ribs and $0.70 \mathrm{~m}$ prefabricated concrete hollow blocks. The balconies have solid concrete floor slabs $0.20 \mathrm{~m}$ thick. The height between floors varies between $2.65 \mathrm{~m}$ and $4.45 \mathrm{~m}$ and spans measure $4.60 \times 7.00 \mathrm{~m}$ and $4.60 \times 5.75 \mathrm{~m}$. A view of this building under construction can be seen in Figure 3. The concrete used for all structural elements had a characteristic compressive strength of $25 \mathrm{MPa}$.

To be able to measure temperature variations inside the concrete slabs and evaluate the thermal gradients, a total of five thermocouples were arranged in the floor slab during casting at distances of 0.05 , $0.10,0.175,0.25$ and $0.30 \mathrm{~m}$ from the upper surface (see Fig.4). One of the balconies was also equipped with three thermocouples at depths of $0.05,0.10$ and $0.15 \mathrm{~m}$. Ambient temperatures were measured by a 
free thermocouple. Readings were recorded by a measuring station (MS) as shown in Figure 5, composed of a network module, data acquisition module connected to the thermocouples and a laptop computer equipped with ICITECH software.

\subsection{Description of the Valencia building}

The construction of the final phase of the Faculty of Fine Arts building within the campus of the Polytechnic University of Valencia was also monitored. The building has six storeys and one basement, with all floors made of waffle slabs $0.40 \mathrm{~m}$ thick $(0.35+0.05)$, with a $0.15 \mathrm{~m}$ rib and $0.80 \mathrm{x} 0.80 \mathrm{~m}$ waffle. Spans measure 5.50x8.00 $\mathrm{m}$ and 5.50x8.80 $\mathrm{m}$ and there is an cantilever on the building's south-east side. The height between floors varies between 2.90 and $4.00 \mathrm{~m}$. A view of the building under construction is shown in Figure 6. The concrete used for all structural elements had a characteristic compressive strength of $30 \mathrm{MPa}$. Two ribs of two consecutive slabs (Slabs 1 and 2) were fitted with instrumentation to study thermal gradients. Four thermocouples were embedded in each slab at depths of $0.05,0.10,0.20$ and 0.30 m. Ambient temperatures were measured by a free thermocouple. The test data were recorded by similar equipment to that used in the Sabadell building.

\section{Summary of readings}

\subsection{Experimental building}

Figures 7 and 8 show the concrete temperatures recorded by the different thermocouples in Slab 1 (Concrete 1, 2, 3 and 4) and Slab 2 (Concrete 1, 2 and 3), shores and atmosphere. It can be seen that the shore temperature is practically identical to the ambient temperature. However, slab temperatures follow the same trend as atmospheric temperatures with a certain time lag and never quite reach atmospheric maximums.

Figures $9 \mathrm{a}$ and $9 \mathrm{~b}$ show average load variations in the shores of Slabs 1 and 2 during construction. An analysis of these figures shows that the average load $\left(Q_{\text {med }}\right)$ on all the shores supporting the slabs decreases when the temperature raises and increases when the temperature falls. The average load per square meter on the shores $\left(\mathrm{kN} / \mathrm{m}^{2}\right)$ is obtained as the sum of the loads of the instrumented shores, divided by their tributary area. 
The same behaviour can be deduced from the readings obtained by the LVDTs. Figures 10a and 10b show the variation of the displacement in Slabs 1 and 2, respectively, according to changes in ambient temperature. The behaviour pattern of this variation shows increased slab displacement when the temperature falls and reduced displacement when the temperature rises in LVDT positions 2, 3, 4 and 6. LVDT $\mathrm{N}^{\circ} 5$ showed inverse behaviour, due to the fact that it was located near to the edge of the cantilever.

\subsection{Sabadell building}

Figures 11 to 14 show the internal slab temperature distributions throughout the day. Figures 11 and 13 give the figures for the $0.20 \mathrm{~m}$ and $0.32 \mathrm{~m}$ slabs, respectively, with the formwork still in place. Figures 12 and 14 show the readings for the same slabs with the formwork removed. In all cases it can be seen that early in the morning, with lower ambient temperatures, the lower surface temperature is higher than the upper. As the temperature rises throughout the day, this phenomenon is reversed and the upper surface gives higher readings than the lower.

Maximum and minimum temperature differences between the upper and lower slab surfaces depend on whether or not the formwork is still in place. The values are given in Table 1.

\subsection{Valencia building}

As can be seen in Figures 15, 16 and 17, the temperature distribution inside the slabs throughout the day was similar to that of the Sabadell building. Figure 15 gives readings in the slabs with formwork in place, while figure 16 shows the readings with formwork removed and in direct sunlight, and Figure 17 without formwork and shaded from sunlight by the upper floor. In all cases, during the night and early morning, when the ambient temperature is low, the lower slab surface is at a higher temperature than the upper. As the temperature rises throughout the day this situation is reversed. Table 2 gives temperature differences between the upper and lower slab surfaces in the Valencia building. These variations depend on whether the formwork is in place or has been removed. Some variations are also due to the action of direct sunlight or on whether the slab is shaded from the sun by an upper floor.

\subsection{Critical analysis of the readings from the experimental building}


In the case of Slab 1, mean load per surface unit on the shores, after pouring and until just before clearing, varied between 0.70 and 1.18 times the slab self-weight for temperature variations of up to $8^{\circ} \mathrm{C}$. This means that for a difference of $\pm 1^{\circ} \mathrm{C}$, the mean load per surface unit on the shores varied by \pm 0.34 $\mathrm{kN} / \mathrm{m}^{2}$, which represents $6 \%$ of the slab self-weight. In the same slab after clearing, the maximum variation in average load on shores was 0.26 times the slab self-weight, corresponding to a temperature of $14^{\circ} \mathrm{C}$, which means that for $\mathrm{a} \pm 1^{\circ} \mathrm{C}$ difference the mean shore load per surface unit varied by $0.10 \mathrm{kN} / \mathrm{m}^{2}$, i.e. $2 \%$ of the slab self-weight.

In Slab 2, the mean load per surface unit on the shores, after pouring and until just before clearing, varied between 0.92 and 1.47 times the slab self-weight for a maximum temperature variation of $14^{\circ} \mathrm{C}$. This means that for a difference of $\pm 1^{\circ} \mathrm{C}$, the mean load per surface unit on the shores varied by \pm 0.21 $\mathrm{kN} / \mathrm{m}^{2}$, which represents $3.8 \%$ of the slab self-weight. As occurred in Slab 1, the range of load variations is smaller than in the readings taken before clearing. The maximum variation in mean load on the shores was 0.25 times the slab self-weight, corresponding to a temperature difference of $11^{\circ} \mathrm{C}$. For a temperature difference of $\pm 1^{\circ} \mathrm{C}$ the mean load per surface unit on the shores thus varied $0.13 \mathrm{kN} / \mathrm{m}^{2}$, i.e. $2 \%$ of slab self-weight. In all slabs, regardless of whether or not clearing had been carried out, the same pattern was observed of increased loads with lower ambient temperatures and reduced loads with higher ambient temperatures.

\section{Finite Element Model}

To simulate the experimental building described in Section 2.1, a model based on Alvarado's FEM [6] was developed, using commercial ANSYS 11.0 software [19]. The model considered changes in ambient temperature as well as in temperatures of slabs, shores and columns. The geometric and mechanical characteristics of the elements used in the building construction were also included and the building process used was considered by means of an evolving calculation.

\subsection{Hypotheses considered}

The hypotheses adopted in the FE model were the following:

- Reinforced concrete slabs were assumed to have linear elastic behaviour and stiffness that varies with time. 
- Columns were simulated with linear elastic behaviour and their stiffness was considered to vary with time.

- Steel shores were elastic elements with finite stiffness, supported at the ends. Their chief characteristics are given in Table 3.

- Wooden formwork boards (27 mm thick and elasticity module $10 \mathrm{GPa}$ ) were considered to have linear elastic behaviour and finite stiffness.

- Steel straining pieces (406 $\mathrm{mm}^{2}$ cross section and $210 \mathrm{GPa}$ elasticity modulus) show elastic and linear behaviour with finite stiffness.

- The foundation was considered infinitely stiff. This hypothesis was adopted after establishing that the first set of shores rest directly on the foundation slab.

- Changes of temperature in the different structural elements were considered. Columns and shores were assumed to have a uniform temperature throughout, while slabs have an internal temperature gradient.

- The effects of creep and shrinkage in concrete were not considered.

\subsection{Finite elements and meshing}

Concrete slabs and wooden formwork boards were modelled by two-dimensional SHELL63 elements [20]. The elements were formed by 4 nodes with 6 degrees of freedom per node (translations and rotations in $\mathrm{X}, \mathrm{Y}$ and $\mathrm{Z}$ ).

Steel shores were modelled by 2-node one-dimensional LINK10 elements [20] with 3 degrees of freedom per node (translations in $\mathrm{X}, \mathrm{Y}$ and Z). Options included considering that they were only subjected to compression forces, the ideal for modelling shores.

To model concrete columns and steel straining pieces BEAM44 elements were used [20]. The BEAM44 element has two nodes (I, J) and a third optional node (K) that defines element orientation. This element has 6 degrees of freedom per node (translations and rotations in $\mathrm{X}, \mathrm{Y}$ and $\mathrm{Z}$ ) and allows nodes to be displaced from the section axis (ideal for transferring nodes to each column growthpoint).

The size of the shore mesh is influenced by shore dimensions and the distribution of shoring and formwork components. To obtain a suitable degree of approximation, the FE mesh size used for slabs and 
formwork was $0: 20 \times 0: 20 \mathrm{~m}^{2}$. The mesh size used for concrete columns was $0.58 \mathrm{~m}$ and for straining pieces was $0.20 \mathrm{~m}$.

\subsection{Simulation of the building process}

In order to simulate the building process in the FE model, it was considered that the different support conditions (shores, straining pieces and formwork), concrete mechanical characteristics and the temperatures of the different elements varied with time.

ANSYS 11.0 [19] allows an evolving calculation to be performed by means of different load steps. A load step consists of calculating the structure with the material geometry, properties and the temperatures corresponding to each of the building phases considered. After solving the first load step, the second load step is then based on the load and deformation values obtained from the first. An evolving calculation is thus performed with a load step for each building phase.

To perform this calculation, ANSYS 11.0 [19] has Birth and Death options and the MPCHG command. The Birth and Death option is based on activating and de-activating the structural elements to be calculated. To de-activate structural elements within a load step, the EKILL command is used. This reduces the stiffness value of the element under consideration, multiplying it by a factor of 1.0E-6 (default value assigned by the program, but can be changed). When an element is de-activated, its associated loads are eliminated. To activate an element, the EALIVE command is used. This assigns the appropriate stiffness to the selected elements and recovers the load values associated with them.

The evolution of the concrete elastic modulus in time is performed by the MPCHG command, which enables changing the type of material assigned to the selected elements. Materials can thus be created in the FE model with the appropriate elastic modulus for the age of the concrete for each slab in each construction phase. The elastic modulus of the slab elements can later be changed in each load step according to the age of the concrete in the phase under consideration. The concrete slabs' elastic modulus is obtained from laboratory tests on normalized specimens. The maturity method is used for determining the evolution of the concrete slabs' elastic modulus. This is described in detail in [14] and is similar to that used by Waller et al. [21] and Adam et al. [22].

To consider the temperature change on structural elements with time, ANSYS 11.0 [19] permits assigning different temperature values to each of the structural elements. A uniform temperature across 
the elements is considered for steel shores (LINK10 element) and concrete columns (BEAM44 element). On the other hand, a linear temperature gradient between the upper and lower slab surfaces is considered for concrete slabs.

The load steps followed in the FE model correspond to the different building phases and to variations in maximum and minimum temperatures between phases. The phases corresponding to each load step are as follows:

- $\quad$ Load Step 1: Casting of Level 1 (Day 0)

- $\quad$ Load Steps 2-7: Temperature variations (Days 1-3)

- $\quad$ Load Step 8: Clearing of Level 1 (Day 3)

- Load Steps 9-17: Temperature variations (Days 3-6)

- $\quad$ Load Step 18: Casting of Level 2 (Day 7)

- Load Steps 19-29: Temperature variations (Days 7-13)

- $\quad$ Load Step 30: Clearing of Level 2 (Day 13)

- $\quad$ Load Steps 31-34: Temperature variations (Days 13-14)

- $\quad$ Load Step 35: Striking of Level 1 (Day 14)

- $\quad$ Load Steps 36-42: Temperature variations (Days 14-17)

\subsection{Temperatures considered}

In the case of shores, the rise in temperature is considered to be equal to the rise in ambient temperature. For columns, as Fang et al [19] have shown, temperature tends to follow ambient temperature, but lags behind and does not reach the same level. The temperature variations in slabs considered in the FEM are shown in Table 4. These temperatures were estimated from readings taken in the experimental building (see Figs.7-8) and from an analysis of the maximum and minimum gradients measured in the buildings of Sabadell and Valencia (see Tables 1-2). An allowance was made for the 0.25 $\mathrm{m}$ thickness of the slab in the experimental building and the fact that it had been constructed in winter, while the other two buildings were built in spring and summer. The temperature differences between upper and lower surface of the slab are of a similar order of magnitude of those prescribed by Eurocode 1 (section 6.1.4) [23] for concrete bridges. 


\subsection{FEM results compared to readings taken in the experimental building}

Figures 18 and 19 provide a comparison of average load increases in the experimental building and those obtained from the FEM for Slabs 1 and 2, respectively. In both cases, the behaviour patterns due to temperature variation are pretty similar; a rise in temperature causes a drop in the load on shores and viceversa.

The shores supporting Slab 1, for temperature rises of up to $13^{\circ} \mathrm{C}$, present a maximum load increase solely due to temperature of $1.41 \mathrm{kN} / \mathrm{m}^{2}$ in the experimental readings and $1.67 \mathrm{kN} / \mathrm{m}^{2}$ in the FEM.

The shores supporting Slab 2 experienced the maximum load variation solely due to temperature of $2.26 \mathrm{kN} / \mathrm{m}^{2}$ in the experimental readings and $1.07 \mathrm{kN} / \mathrm{m}^{2}$ in the FEM, for a maximum temperature variation of up to $9.65^{\circ} \mathrm{C}$. These maximum values occurred between the casting and clearing of Slab 2 .

The range of load variations due to temperature after clearing of slabs is smaller than that found when slabs are supported by the full set of shores.

Figure 20 shows slab deflection and load increments on shores due to changes in temperature between load steps 14 and 15 . In order to distinguish between the effects of temperature changes on columns and shores and those of the temperature gradient in the slab, the figure shows the deformation of the structure and the load increments in shores due to each of them. Between load steps 14 and 15 temperature experiences the following changes:

a. Dead load increment: There is no dead load increment between load steps 14 and 15 .

b. Difference in temperature between upper and lower surface of slab (G):

Load step 14: $\mathrm{G}=-0.6^{\circ} \mathrm{C}$ (negative gradient: lower surface warmer than upper surface) Load step 15: $\mathrm{G}=+3.0^{\circ} \mathrm{C}$ (positive gradient: upper surface warmer than lower surface) Variation in temperature difference between load steps 14 and $15:+3.6^{\mathrm{a}} \mathrm{C}$.

c. Temperature rise in shores: $\quad 12.1^{\circ} \mathrm{C}$ Temperature rise in columns: $\quad 10.1^{\circ} \mathrm{C}$

These changes in temperature have induced the following average load increments in shores, $\overline{\Delta Q_{s h}}$ (for the sole purpose of this single calculation between load steps, tension in shores has been enabled) :

$\begin{array}{ll}\text { a. Dead load increment: } & \overline{\Delta Q_{\text {sh } 1}}=0.00 \mathrm{kN} / \mathrm{m}^{2}\end{array}$

b. Temperature rise on slab

(Difference in temperature between upper and lower surface of slab): $\overline{\Delta Q_{s h, 2}}=-1.20 \mathrm{kN} / \mathrm{m}^{2}$ 
c. Temperature rise in shores and columns:

$\overline{\Delta Q_{\text {sha }}}=+0.43 \mathrm{kN} / \mathrm{m}^{2}$

Combined effect of temperature changes between load steps 14 and $15: \quad \overline{\Delta Q_{\text {sh }}}=-0.77 \mathrm{kN} / \mathrm{m}^{2}$

\section{Conclusions and future work}

This paper presents the results of experimental readings taken in three different building works to study the effect of temperature variations on the loads on shores in the course of the construction process. The evolution of both, ambient temperature and temperature variations inside slabs were measured. It has been observed the magnitude and importance of temperature gradients in the slabs.

It was found that, in general, at night and in the early hours of the morning, with low ambient temperatures, the lower surface of the slab presents a higher temperature than the upper. As the ambient temperature rises throughout the day this phenomenon is reversed and the upper surface is at a higher temperature than the lower. It was also found that temperature variations were affected by the fact of the formwork being in place or having been removed.

The basic results of these measurements were used in conjunction with experimental results obtained from shoring loads and from the FE model of the building constructed in the grounds of the ICITECH laboratory (see Alvarado [14]) to study the influence of temperature changes on the loads on shores and slabs during the building process.

Both the FE model and the experimental results were seen to present the same behaviour patterns in the presence of temperature changes, which - in the case of the experimental building studied - consisted of a reduced load on shores when temperatures rose and increased loads when temperatures fell. This behaviour is mainly caused by the influence of a temperature gradient across the concrete slab. For a difference of $\pm 1^{\circ} \mathrm{C}$, the load per surface unit on shores varied between $0.13 \mathrm{kN} / \mathrm{m}^{2}$ and $0.34 \mathrm{kN} / \mathrm{m}^{2}$, which represented between $2 \%$ and $6 \%$ of slab self-weight.

These results show the importance of temperature variations in the loads on shores and slabs during construction of multistory buildings. These changes in loads are the product of the combination of two main effects: (a) temperature changes on columns and shores and (b) the temperature difference between the upper and the lower surface of the slabs. This approach to the problem and its verification by an experimental building and a finite element model can be considered the main novelties of this paper. 
As a future line of research, different structural configurations and different types of temperature variation -e.g., a bigger thermal inertia of the columns may lead to bigger differences between temperatures in columns and shores, or the temperature difference across the slab may vary due to different insolation patterns- should be checked to observe what is the range of expected load increments due to changes in temperature.

\section{Acknowledgements}

The authors would like express their gratitude to the Spanish Ministry for Science and Technology for funding the project (BIA2004-02085) and also to the Encofrados J. Alsina formwork company for their invaluable assistance. 


\section{References}

[1] Kaminetzky D, Stivaros P. Early-age concrete: construction loads, behavior, and failures. Concrete International 1994;16(1):58-63.

[2] Kaminetzky D. Design and construction failures: Lessons from forensic investigations. MacGraw-Hill, New York, 1991.

[3] Epaarachchi D, Stewart M, Rosowsky D. Structural reliability of multistory buildings during construction. Journal of Structural Engineering 2002;128(2):205-13.

[4] Moragues JJ, Catalá J, Pellicer E. An analysis of concrete framed structures during the construction process. Concrete International 1996;18(11):44-8.

[5] Alvarado YA, Calderón PA, Adam JM, Payá IJ, Pellicer T, Pallares FJ, Moragues JJ. An experimental study into the evolution of loads on shores and slabs during construction of multistory buildings using partial striking. Engineering Structures 2009;31(9):2132-40

[6] Alvarado YA, Calderón PA, Gasch I, Adam JM. A numerical study into the evolution of loads on shores and slabs during construction of multistorey buildings. Comparison of partial striking with other techniques. Engineering Structures 2010;32(10):3093-102

[7] Grundy P, Kabaila A. Construction loads on slabs with shored formwork in multistory buildings. ACI Journal Proceedings 1963;60(12):1729-38.

[8] Liu XL, Chen WF, Bowman MD. Construction load analysis for concrete structures. Journal of Structural Engineering ASCE 1985;111(5):1019-36.

[9] Stivaros PC, Halvorsen GT. Shoring/reshoring operations for multistory buildings. ACI Structural Journal 1990;87(5):589-96.

[10] Mossallam KH, Chen WF. Determining shoring loads for reinforced concrete construction. ACI Structural Journal 1991;88(3):340-50.

[11] Duan MZ, Chen WF. Improved simplified method for slab and shore load analysis during construction. Project report CE-STR-95-24. Purdue University, West Lafayette, Ind; 1995.

[12] Fang DP, Geng CD, Zhu HY, Liu XL. Floor load distribution in reinforced concrete buildings during construction. ACI Structural Journal 2001;98(2):149-56.

[13] Beeby AW. The forces in backprops during construction of flat slab structures. Proceedings of the ICE - Structures and Buildings 2001;146(3):307-17.

[14] Alvarado YA. Estudio experimental y numérico de la construcción de forjados hormigonados in situ mediante procesos de cimbrado, clareado y descimbrado de plantas consecutivas. $\mathrm{PhD}$ Thesis. Universidad Politécnica de Valencia 2009. Available at http://hdl.handle.net/10251/7285. [In Spanish]

[15] Calderón PA, Alvarado YA, Adam JM. A new simplified procedure to estimate loads on slabs and shoring during the construction of multistorey buildings. Engineering Structures (2011), doi: 10.1016/j.engstruct.2011.01.027 
[16] Rosowsky DV, Philbrick Jr. TW, Huston DR. Observations from shore load measurement during concrete construction. Journal of Performance of Constructed Facilities 1997;11(1) :18-23.

[17] Fang DP, Zhu HY, Geng CD, Liu XL. On-site measurements of structural characteristics of reinforced concrete buildings during construction. ACI Structural Journal 2001;98(2):157-63.

[18] Fang DP Xi H, Wang X, Zhang Ch. Influences of shrinkage, creep, and temperature on the load distributions in reinforced concrete buildings during construction. Tsinghua Science And Technology 2009;14(6):756-64.

[19] ANSYS 11.0. Theory reference. ANSYS Inc.; 2006.

[20] ANSYS 11.0. Element reference. ANSYS Inc.; 2006.

[21] Waller V, d'Aloïa L, Cussigh F, Lecrux S. Using the maturity method in concrete cracking control at early ages. Cement \& Concrete Composites 2004;26:589-99.

[22] Adam JM, Pallarés FJ, Calderón PA, Payá IJ. A study of the conditions of use of a new safety system for the building industry. Eng Struct 2007;29(8):1690-7.

[23] ENV 1991-2-5 (Eurocode No. 1). Actions on structures. Part 5: Thermal actions. 1991. 


\section{Index of Figures}

Fig. 1. Experimental building.

Fig. 2. Arrangement of LVDTs and thermocouples.

Fig. 3. Sabadell building.

Fig. 4 Thermocouples embedded in column head (Sabadell).

Fig. 5. Measuring station (MS).

Fig. 6. Faculty of Fine Arts building (Valencia).

Fig. 7. Ambient temperatures and temperatures measured in concrete and shores for Slab 1 in experimental building.

Fig. 8. Ambient temperatures and temperatures measured in concrete and shores for Slab 2 in experimental building.

Fig. 9. Mean load coefficients in shores (a) under Slab 1; (b) under Slab 2.

Fig. 10. Deformation in (a) Slab 1; (b) Slab 2.

Fig. 11. Internal temperature distribution throughout the day for a $0.20 \mathrm{~m}$ slab supported by formwork (Sabadell building).

Fig. 12. Internal temperature distribution throughout the day for a $0.20 \mathrm{~m}$ slab without formwork (Sabadell building).

Fig. 13. Internal temperature distribution throughout the day for a $0.32 \mathrm{~m}$ slab supported by formwork (Sabadell building).

Fig. 14. Internal temperature distribution throughout the day for a $0.32 \mathrm{~m}$ slab without formwork (Sabadell building).

Fig. 15. Internal temperature distribution throughout the day for a $0.40 \mathrm{~m}$ slab supported by formwork (Valencia building).

Fig. 16. Internal temperature distribution throughout the day for a $0.40 \mathrm{~m}$ slab without formwork and with direct sunlight (Valencia building).

Fig. 17. Internal temperature distribution throughout the day for a $0.40 \mathrm{~m}$ slab without formwork and away from direct sunlight (Valencia building).

Fig. 18. Increases in temperature and average loads in experimental building and FE model for Slab 1. 
Fig. 19. Increases in temperature and average loads in experimental building and FE model for Slab 2.

Fig. 20. Slab deflection and load increments on shores due to changes in temperature between load steps 14 and 15 . 
Table 1

Temperature differences $\left({ }^{\circ} \mathrm{C}\right)$, maximum and minimum, between the upper and lower slab surfaces in the Sabadell building.

\begin{tabular}{ccccc}
\hline & \multicolumn{2}{c}{ Slab with formwork } & \multicolumn{2}{c}{ Slab without formwork } \\
\hline & $\begin{array}{c}\text { Minimum } \\
\text { differences }\end{array}$ & $\begin{array}{c}\text { Maximum } \\
\text { differences }\end{array}$ & $\begin{array}{c}\text { Minimum } \\
\text { differences }\end{array}$ & $\begin{array}{c}\text { Maximum } \\
\text { differences }\end{array}$ \\
\hline Slab 0.20 m & -0.35 & 1.49 & -0.77 & 3.79 \\
Slab 0.32 m & -1.21 & 2.77 & -1.87 & 5.80 \\
\hline
\end{tabular}

Table 2

Temperature differences $\left({ }^{\circ} \mathrm{C}\right)$, maximum and minimum, between the upper and lower slab surfaces in the Valencia building.

\begin{tabular}{ccccccc}
\hline & \multicolumn{3}{c}{ Slab with formwork } & \multicolumn{4}{c}{ Slab without formwork } \\
\hline & & & Slab with direct sunlight & Slab without direct sunlight \\
\hline & $\begin{array}{c}\text { Minimum } \\
\text { differences }\end{array}$ & $\begin{array}{c}\text { Maximum } \\
\text { differences }\end{array}$ & $\begin{array}{c}\text { Minimum } \\
\text { differences }\end{array}$ & $\begin{array}{c}\text { Maximum } \\
\text { differences }\end{array}$ & $\begin{array}{c}\text { Minimum } \\
\text { differences }\end{array}$ & $\begin{array}{c}\text { Maximum differences } \\
\text { diferencer }\end{array}$ \\
\hline Rib 0.40 m & -2.96 & 6.94 & -3.86 & 9.56 & -1.31 & 7.32 \\
\hline
\end{tabular}

Table 3

Geometrical and mechanical characteristics of the shores

\begin{tabular}{llll}
\hline Length $(\mathrm{m})$ & Diameter $(\mathrm{m})$ & Thickness $(\mathrm{m})$ & Elasticity modulus $(\mathrm{GPa})$ \\
\hline 2.88 & 0.048 & 0.002 & 210 \\
\hline
\end{tabular}

Table 4

Temperature differences $\left({ }^{\circ} \mathrm{C}\right)$, maximum and minimum, between the upper and lower slab surfaces considered in the FEM

\begin{tabular}{cccccc}
\hline \multicolumn{2}{c}{ Slab with formwork } & \multicolumn{2}{c}{$\begin{array}{c}\text { Slab without formwork and with } \\
\text { direct sunlight }\end{array}$} & \multicolumn{2}{c}{$\begin{array}{c}\text { Slab without formwork and } \\
\text { without direct sunlight }\end{array}$} \\
\hline $\begin{array}{c}\text { Minimum } \\
\text { differences }\end{array}$ & $\begin{array}{c}\text { Maximum } \\
\text { differences }\end{array}$ & $\begin{array}{c}\text { Minimum } \\
\text { differences }\end{array}$ & $\begin{array}{c}\text { Maximum } \\
\text { differences }\end{array}$ & $\begin{array}{c}\text { Minimum } \\
\text { differences }\end{array}$ & $\begin{array}{c}\text { Maximum } \\
\text { differences }\end{array}$ \\
\hline-0.3 & 2.4 & -0.6 & 3.0 & -0.4 & 2.0 \\
\hline
\end{tabular}




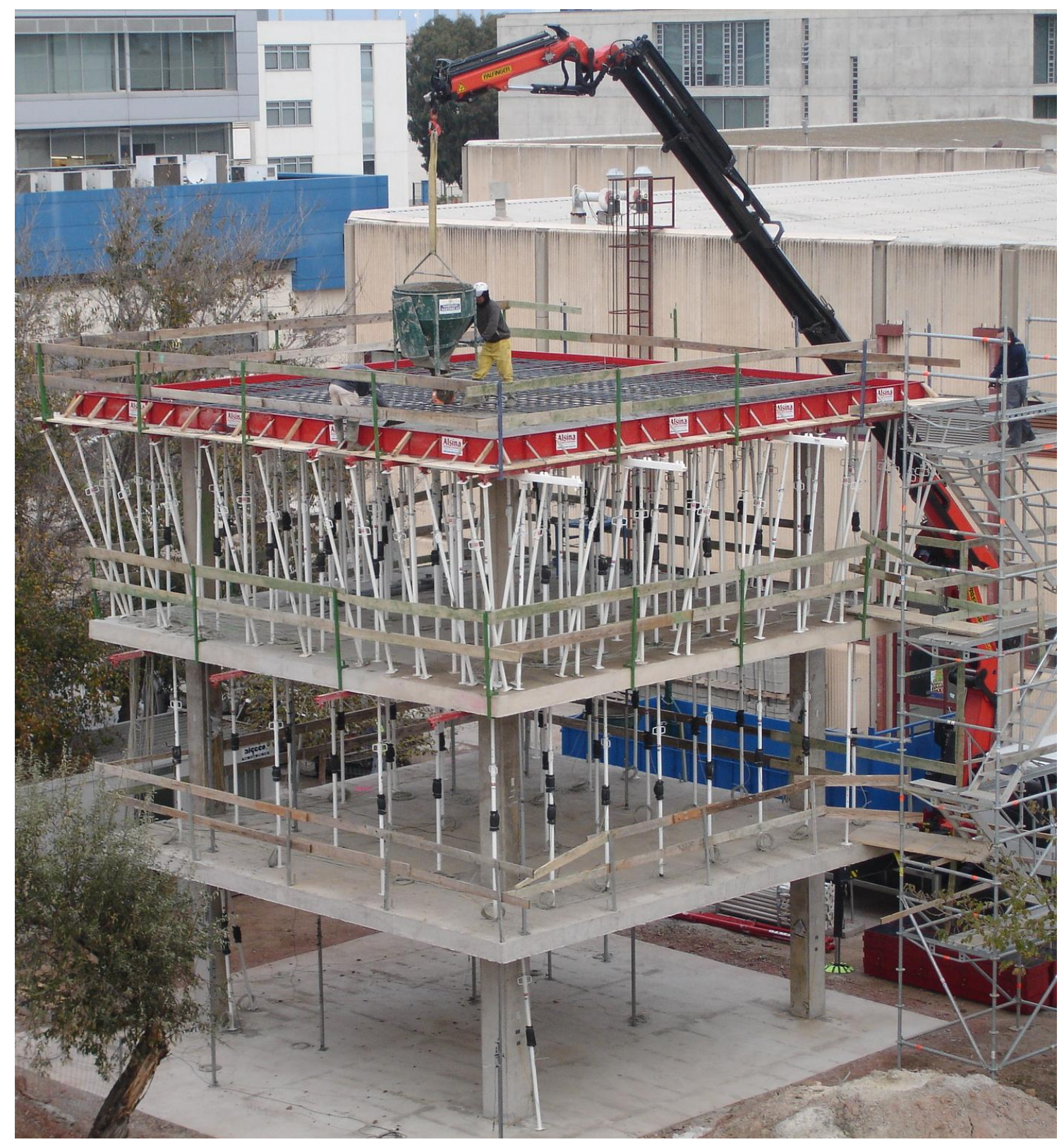

Fig. 1. Experimental building. 


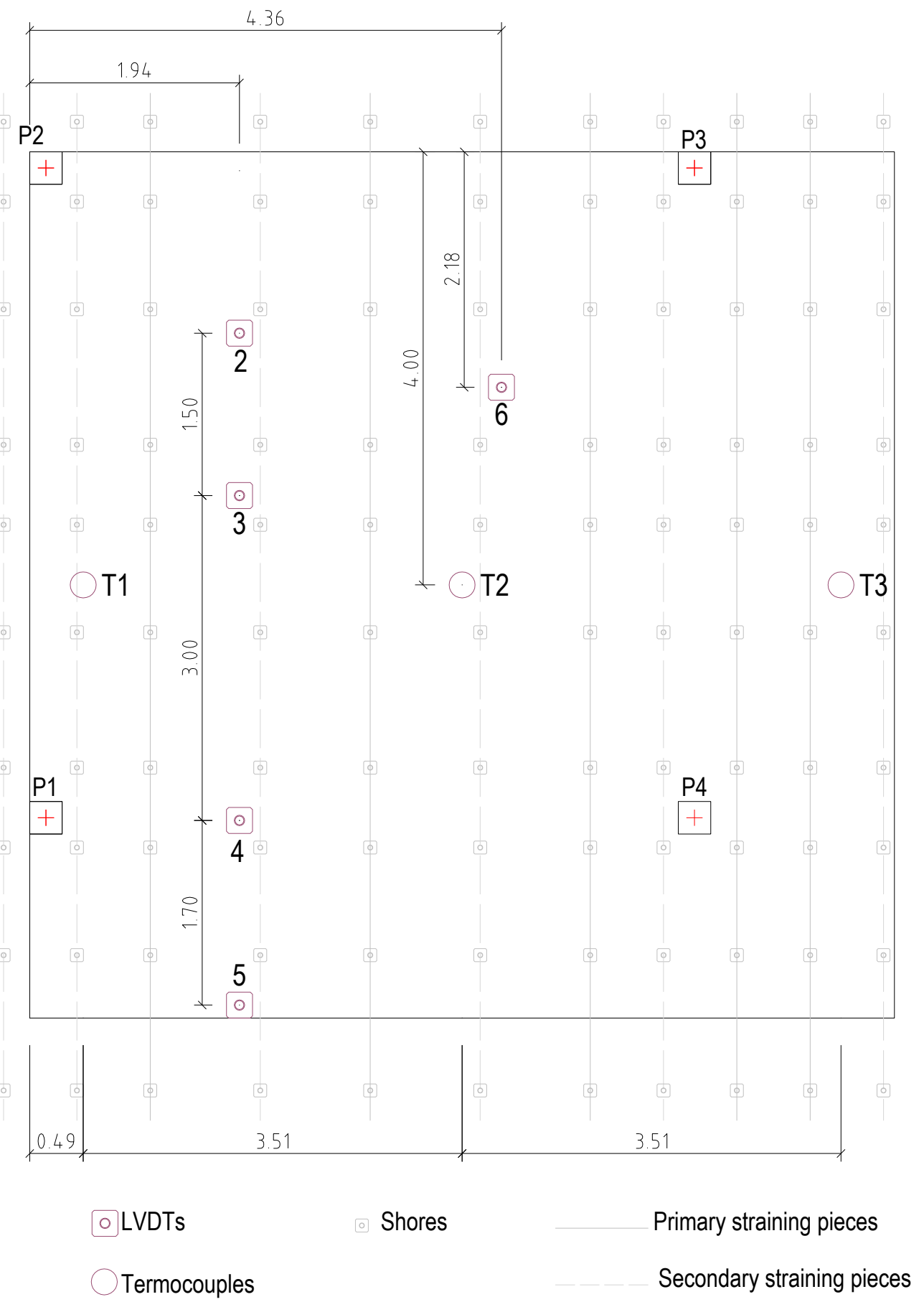

Fig. 2. Arrangement of LVDTs and thermocouples. 


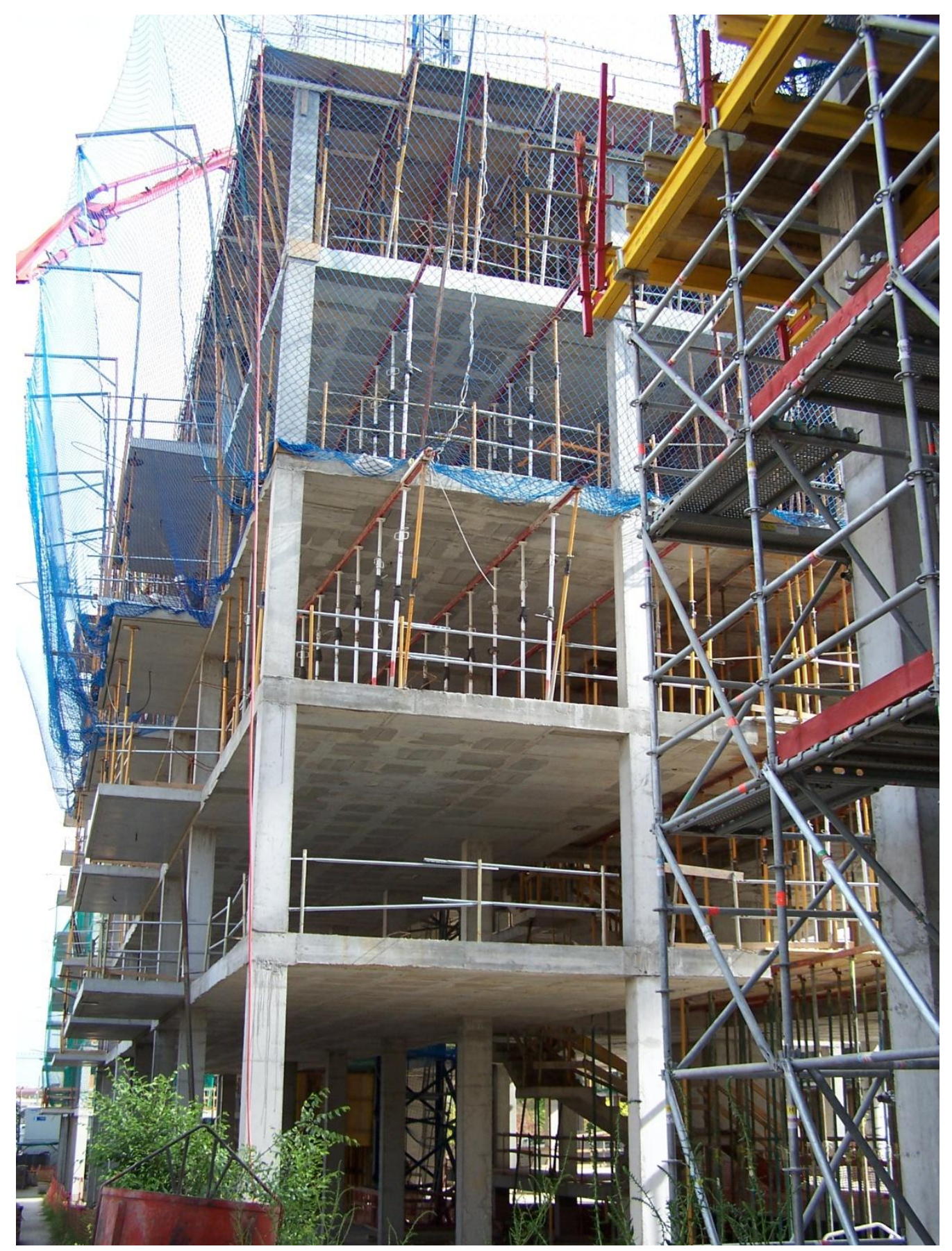

Fig. 3. Sabadell building. 

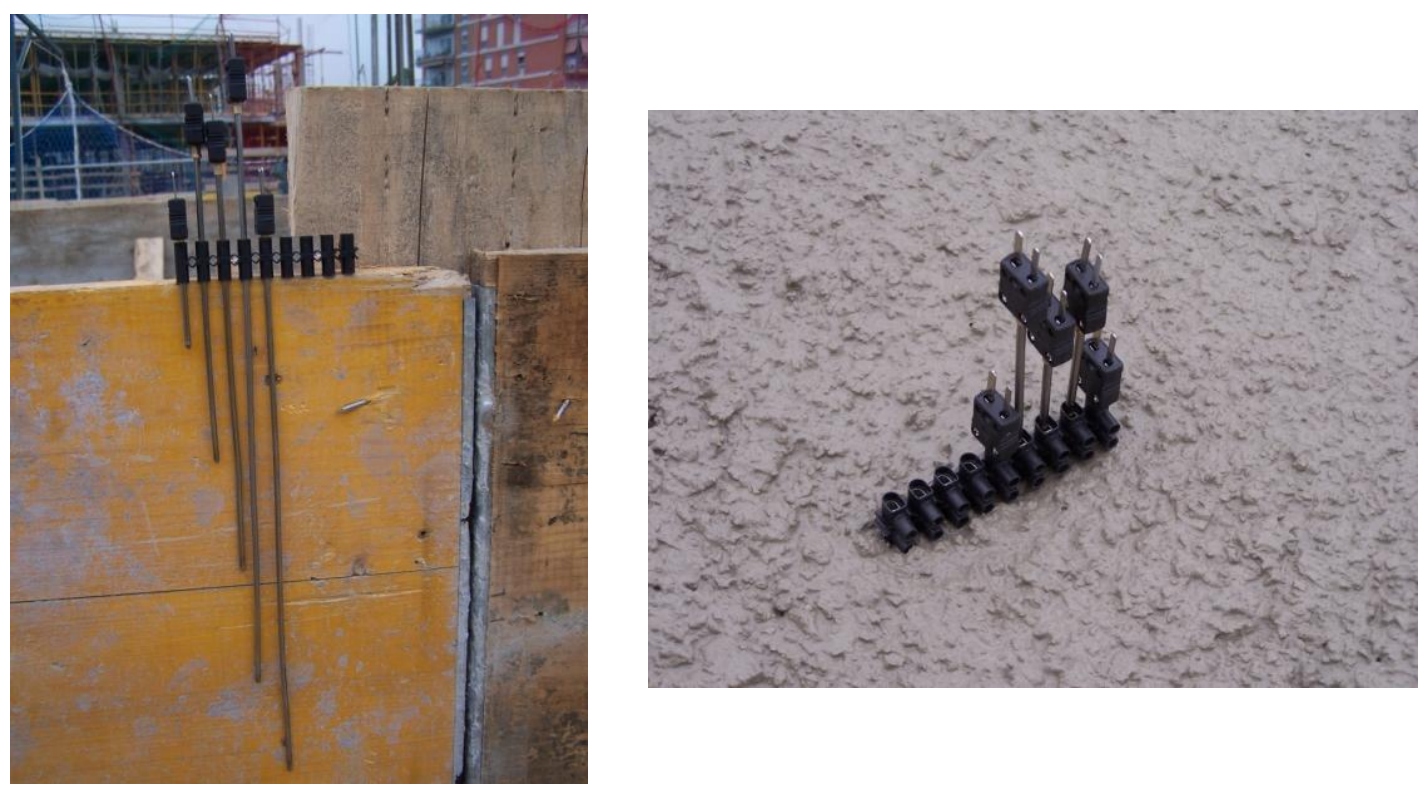

Fig. 4 Thermocouples embedded in floor slab (Sabadell). 


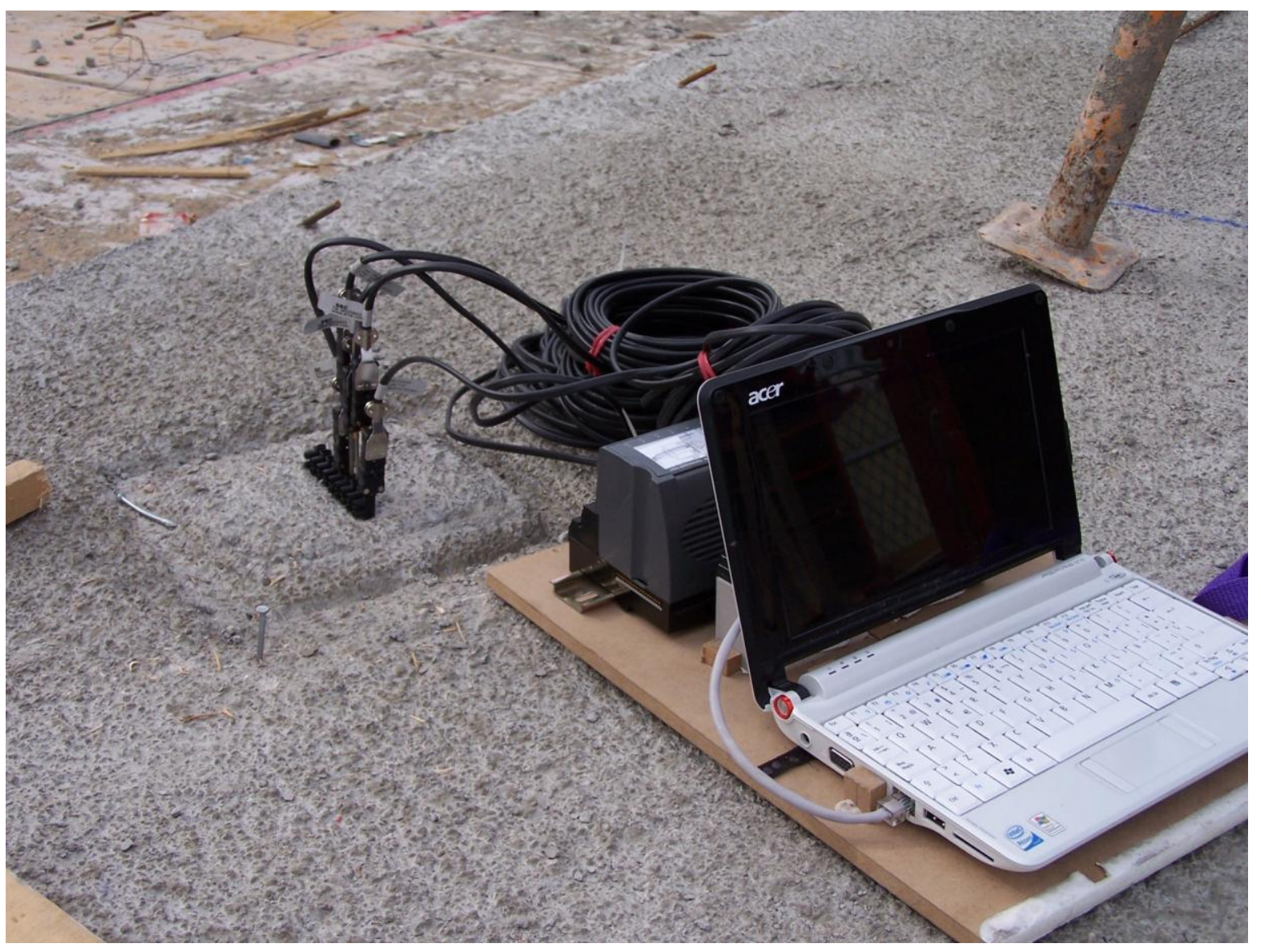

Fig. 5. Measuring station (MS). 


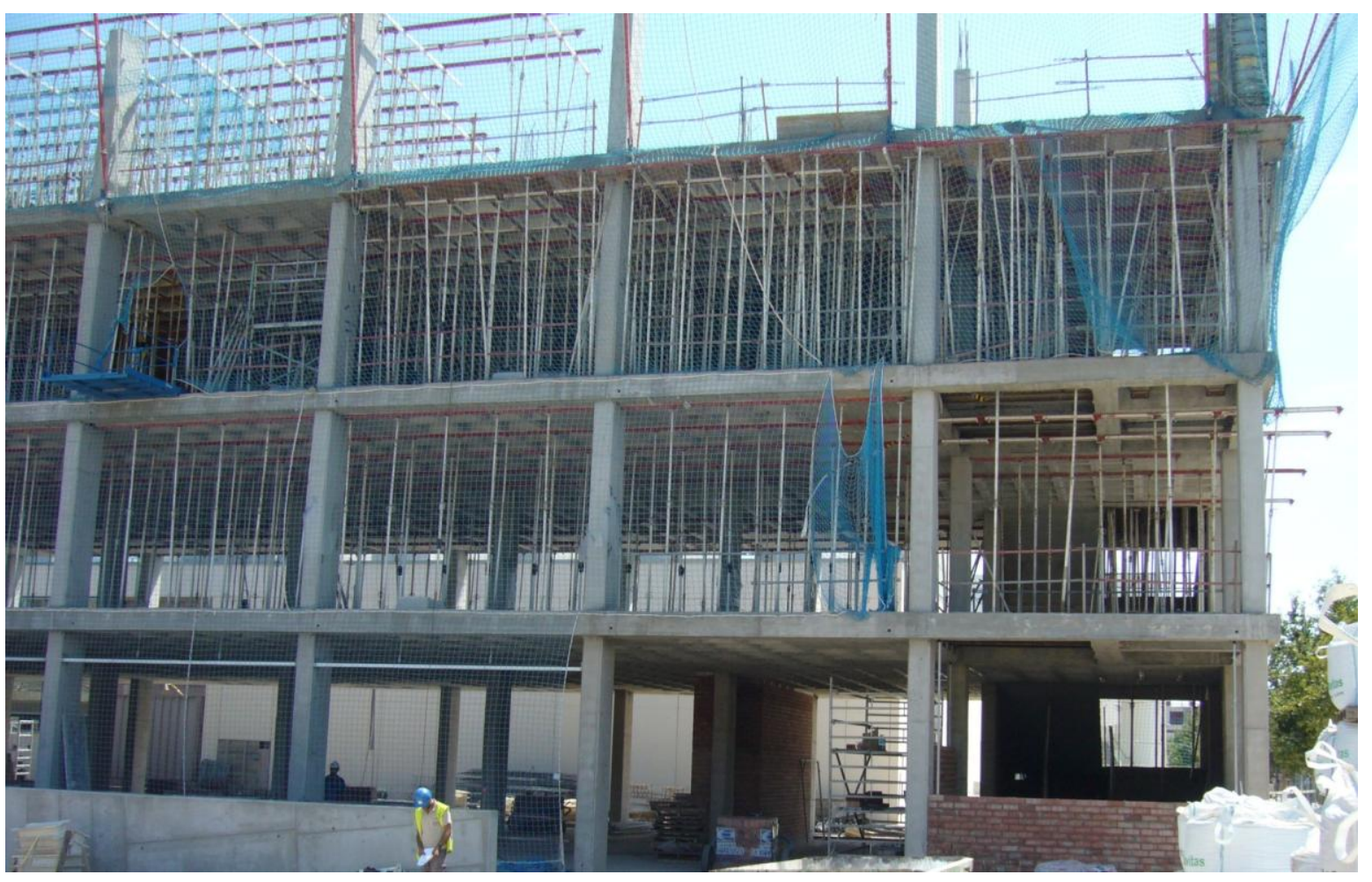

Fig. 6. Faculty of Fine Arts building (Valencia). 


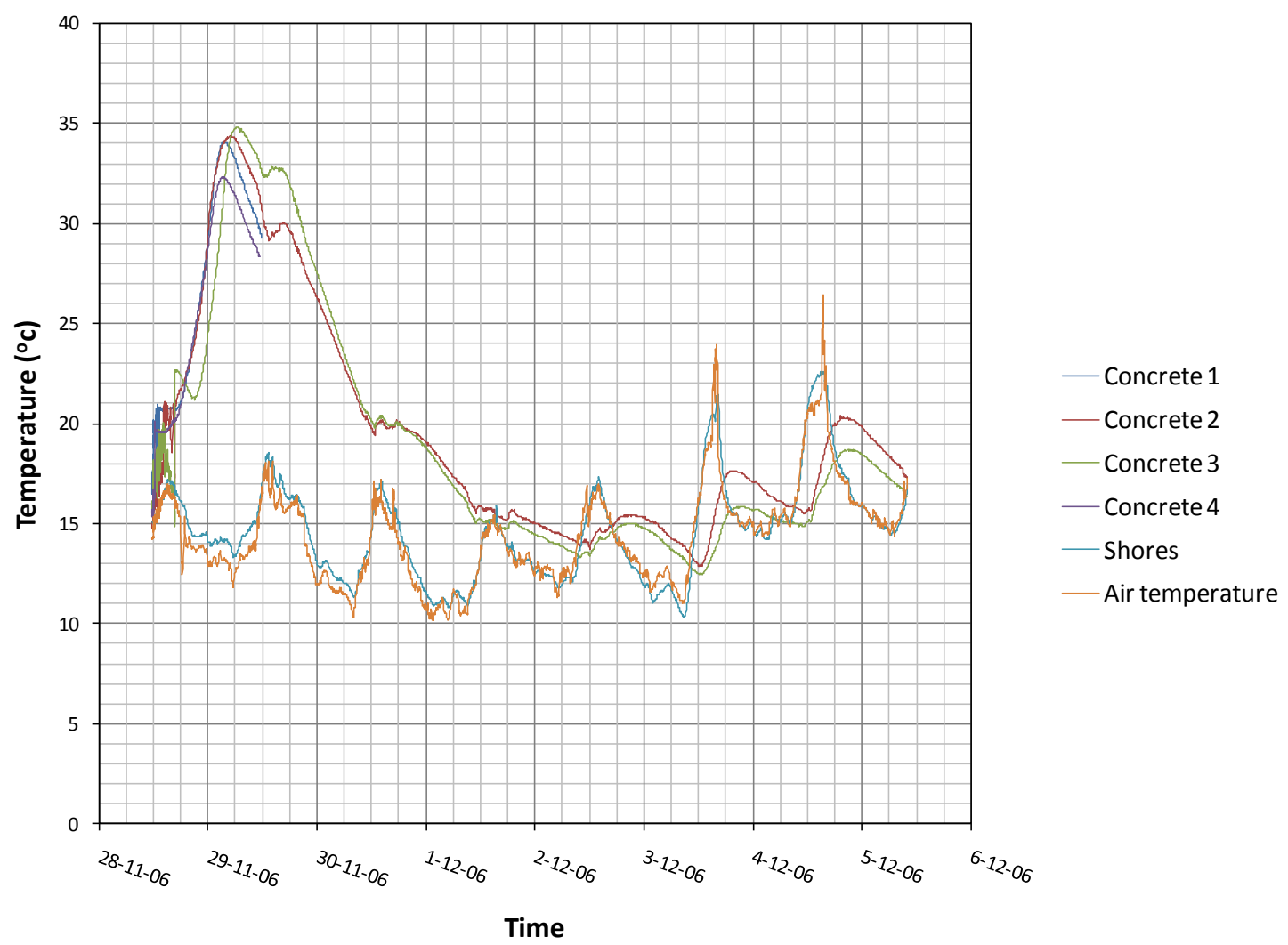

Fig. 7. Ambient temperatures and temperatures measured in concrete and shores for Slab 1 in experimental building. 


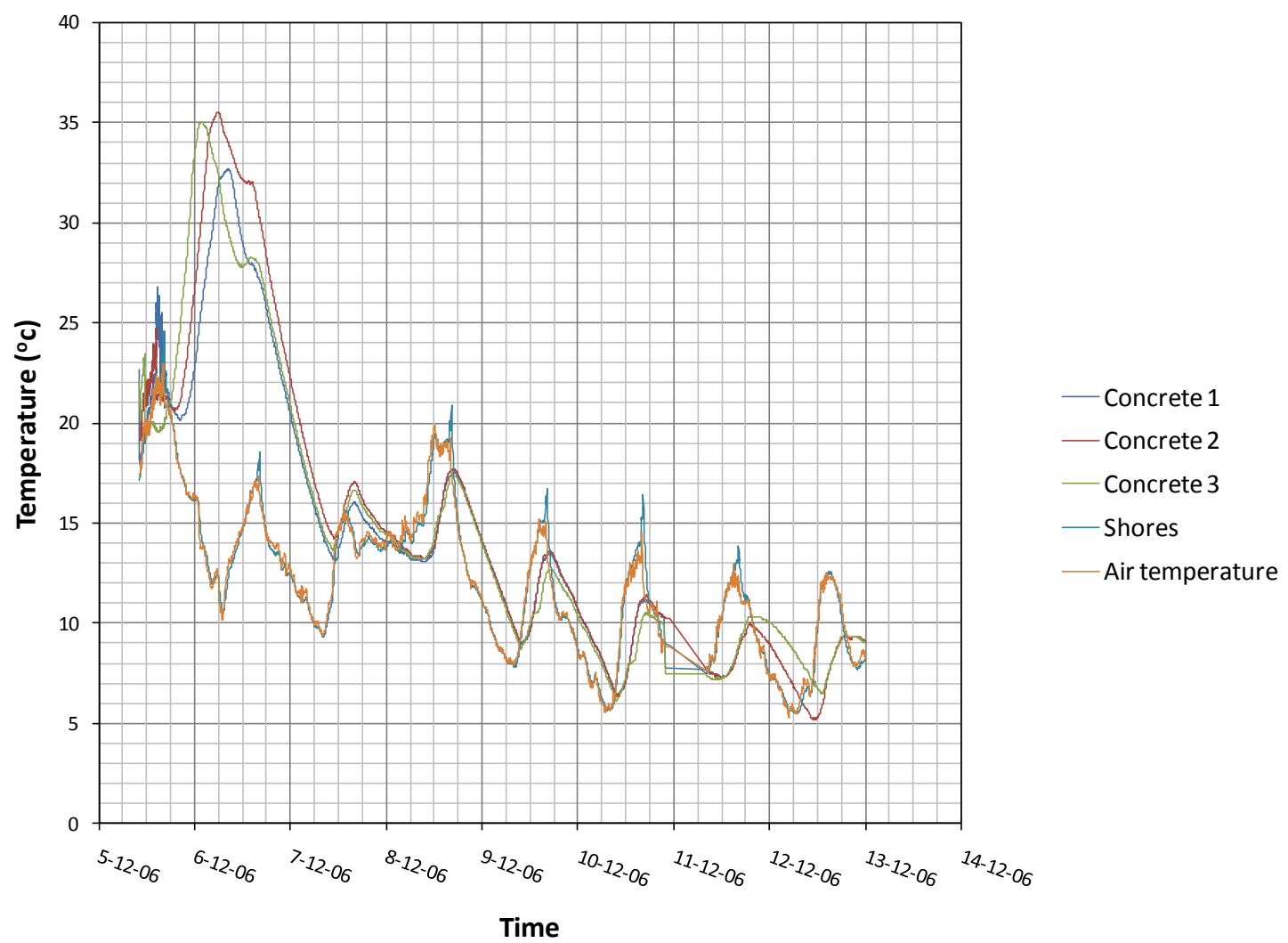

Fig. 8. Ambient temperatures and temperatures measured in concrete and shores for Slab 2 in experimental building. 


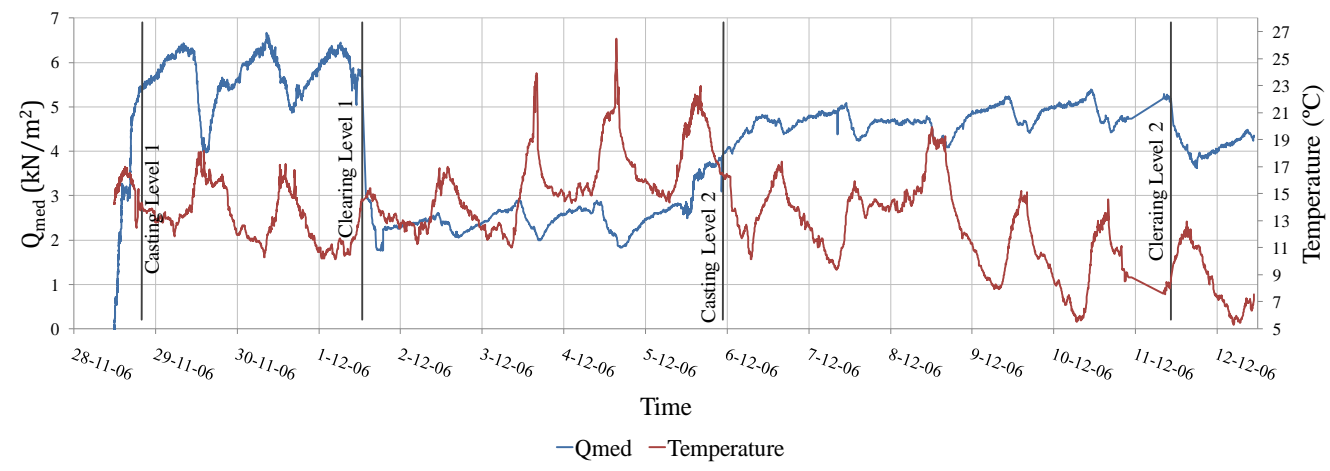

a

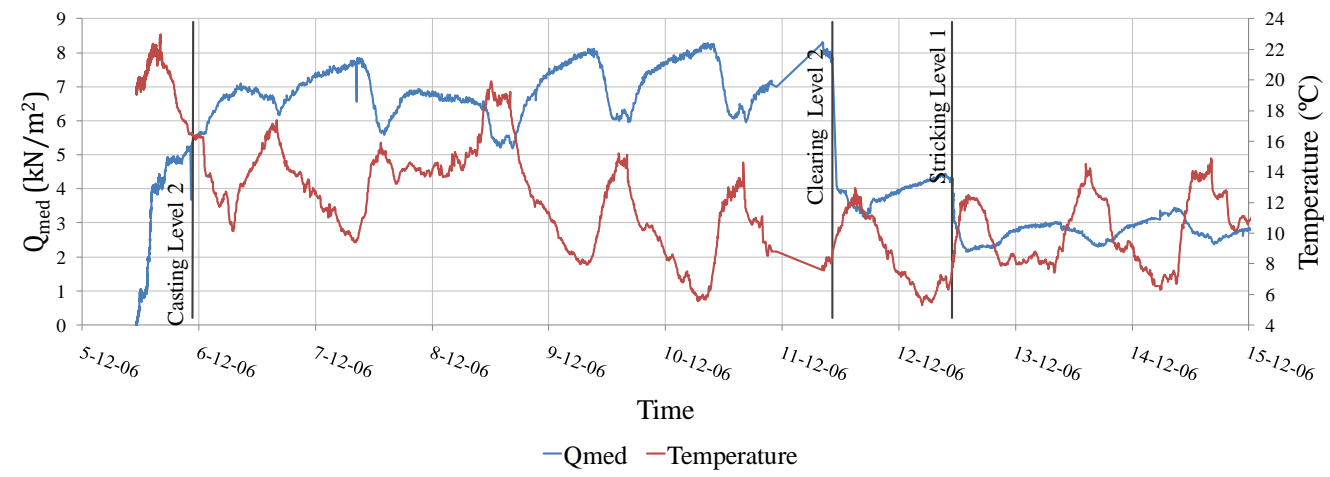

b

Fig. 9. Mean load coefficients in shores (a) under Slab 1; (b) under Slab 2. 


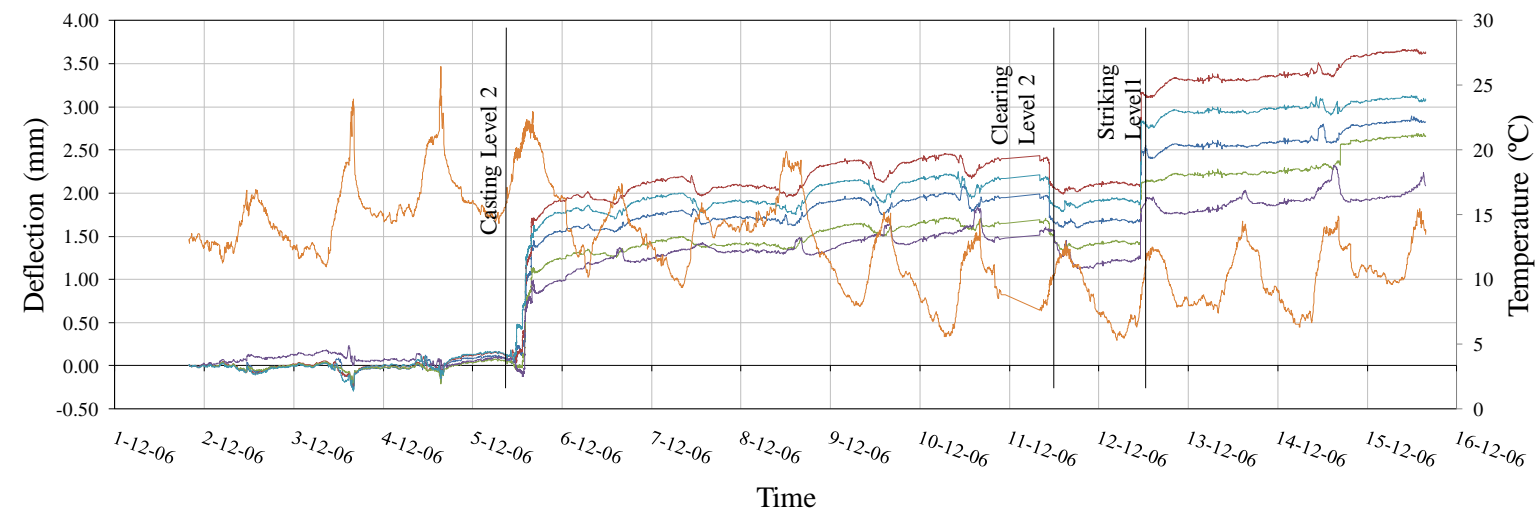

-LVTD $2-$ LVTD $3-$ LVTD $4-$ LVTD $5-$ LVTD $6-$ Temperature

a

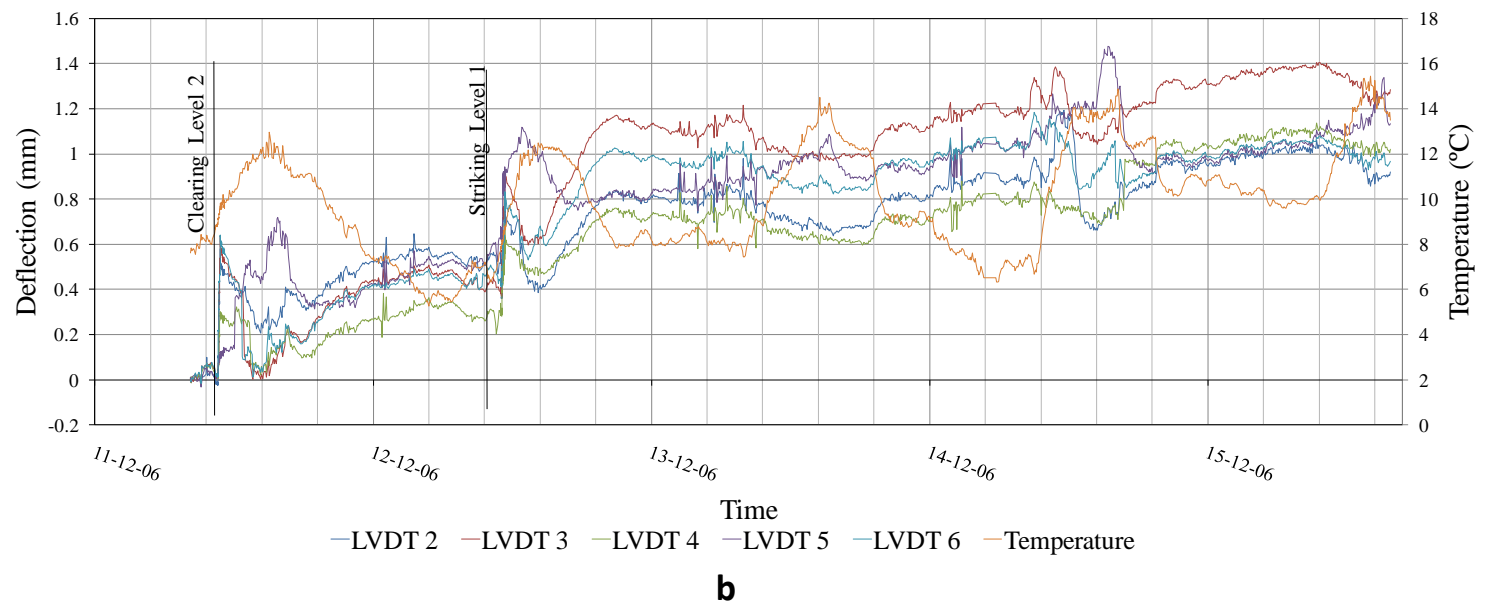

Fig. 10. Deflection in (a) Slab 1; (b) Slab 2. 


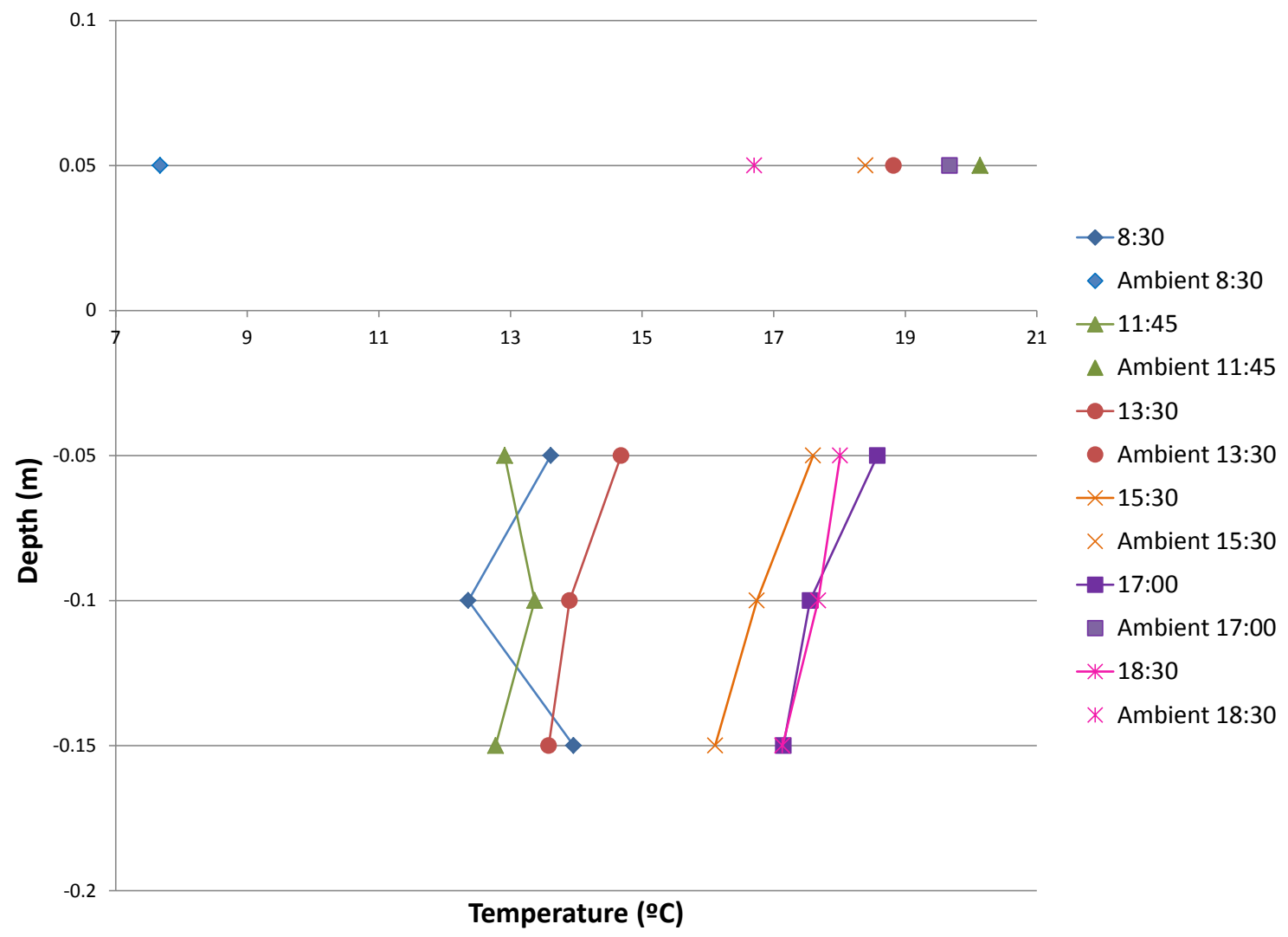

Fig. 11. Internal temperature distribution throughout the day for a $0.20 \mathrm{~m}$ slab supported by formwork (Sabadell building). 


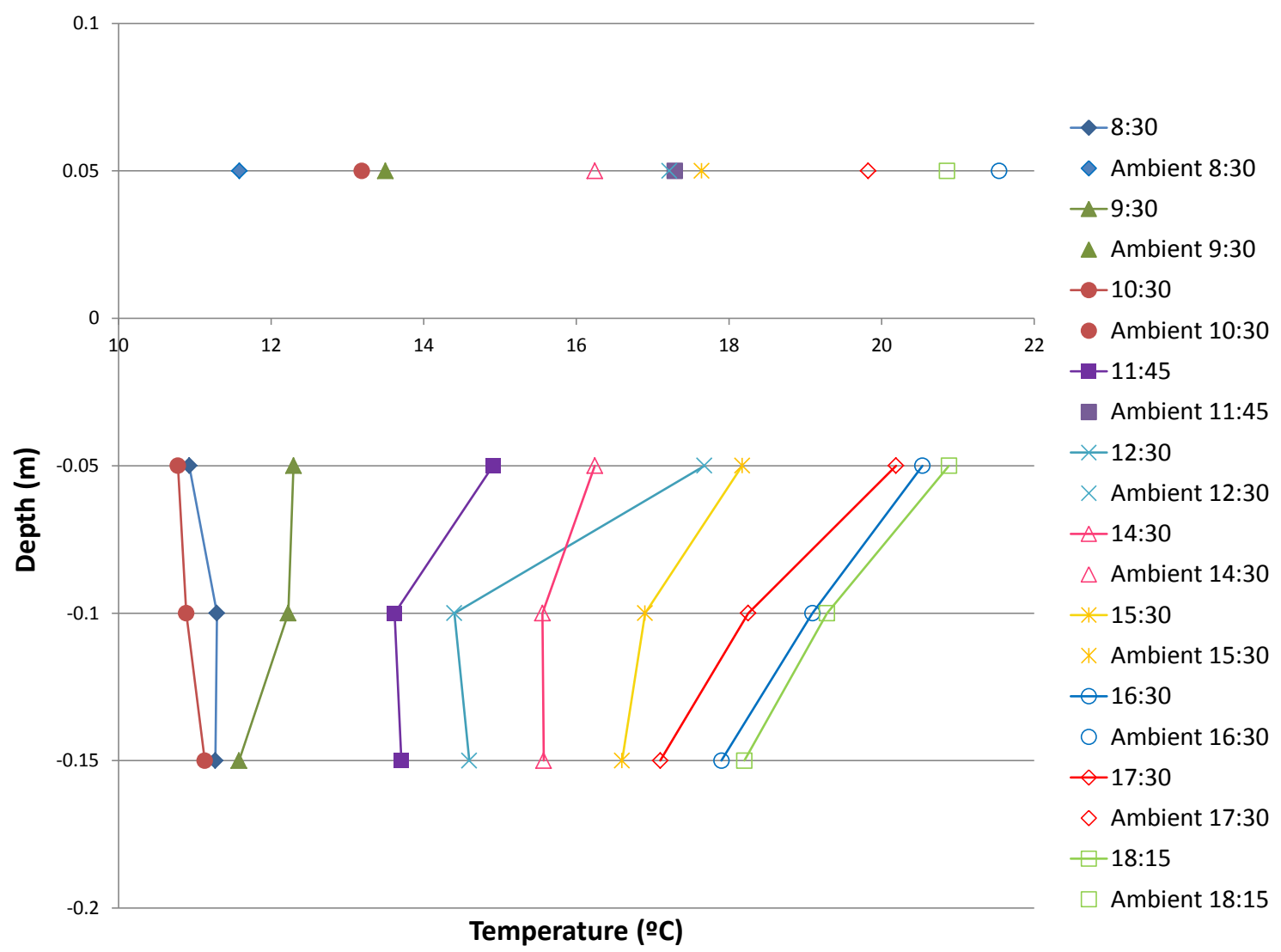

Fig. 12. Internal temperature distribution throughout the day for a $0.20 \mathrm{~m}$ slab without formwork (Sabadell building). 


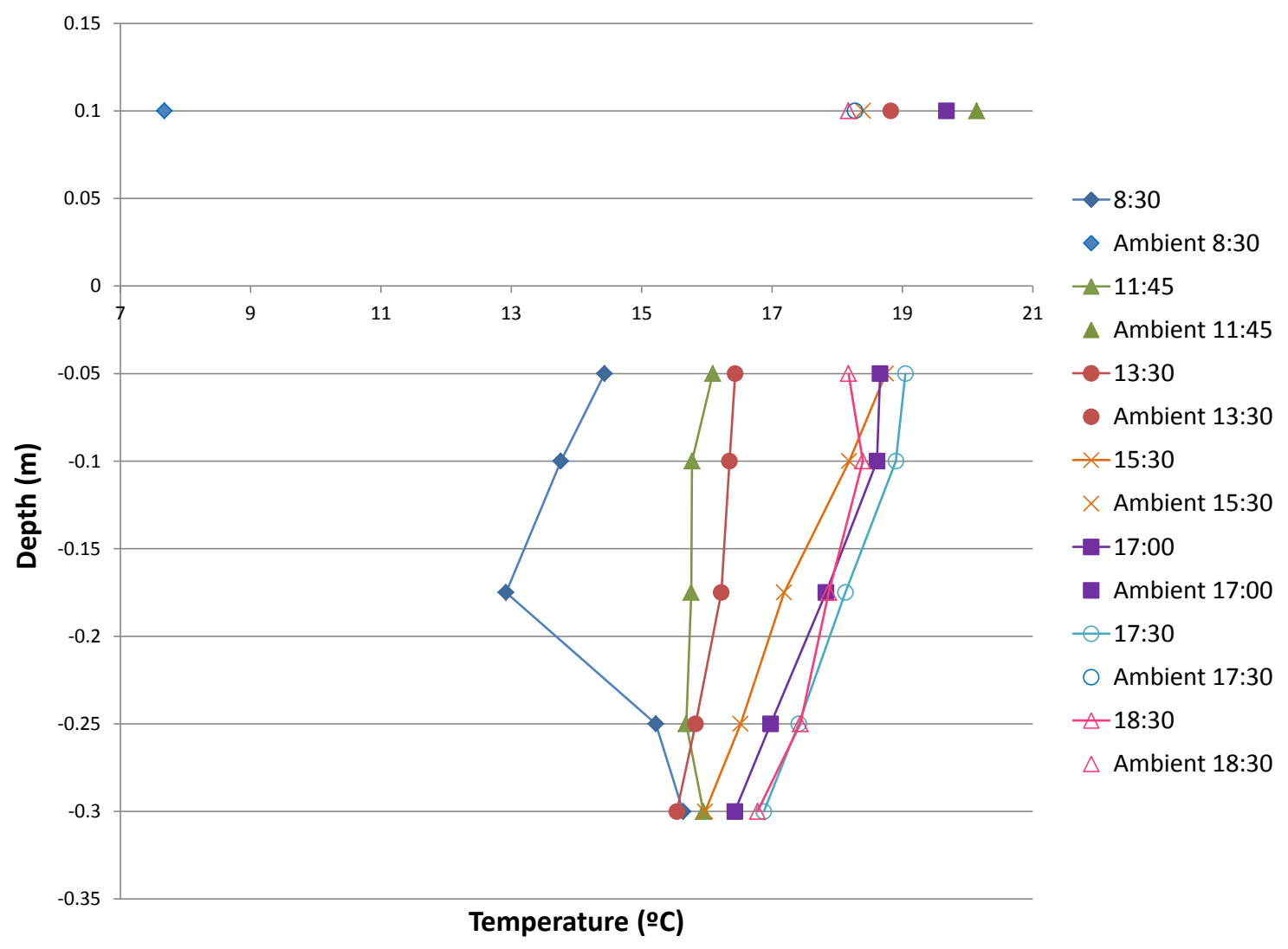

Fig. 13. Internal temperature distribution throughout the day for a $0.32 \mathrm{~m}$ slab supported by formwork (Sabadell building). 


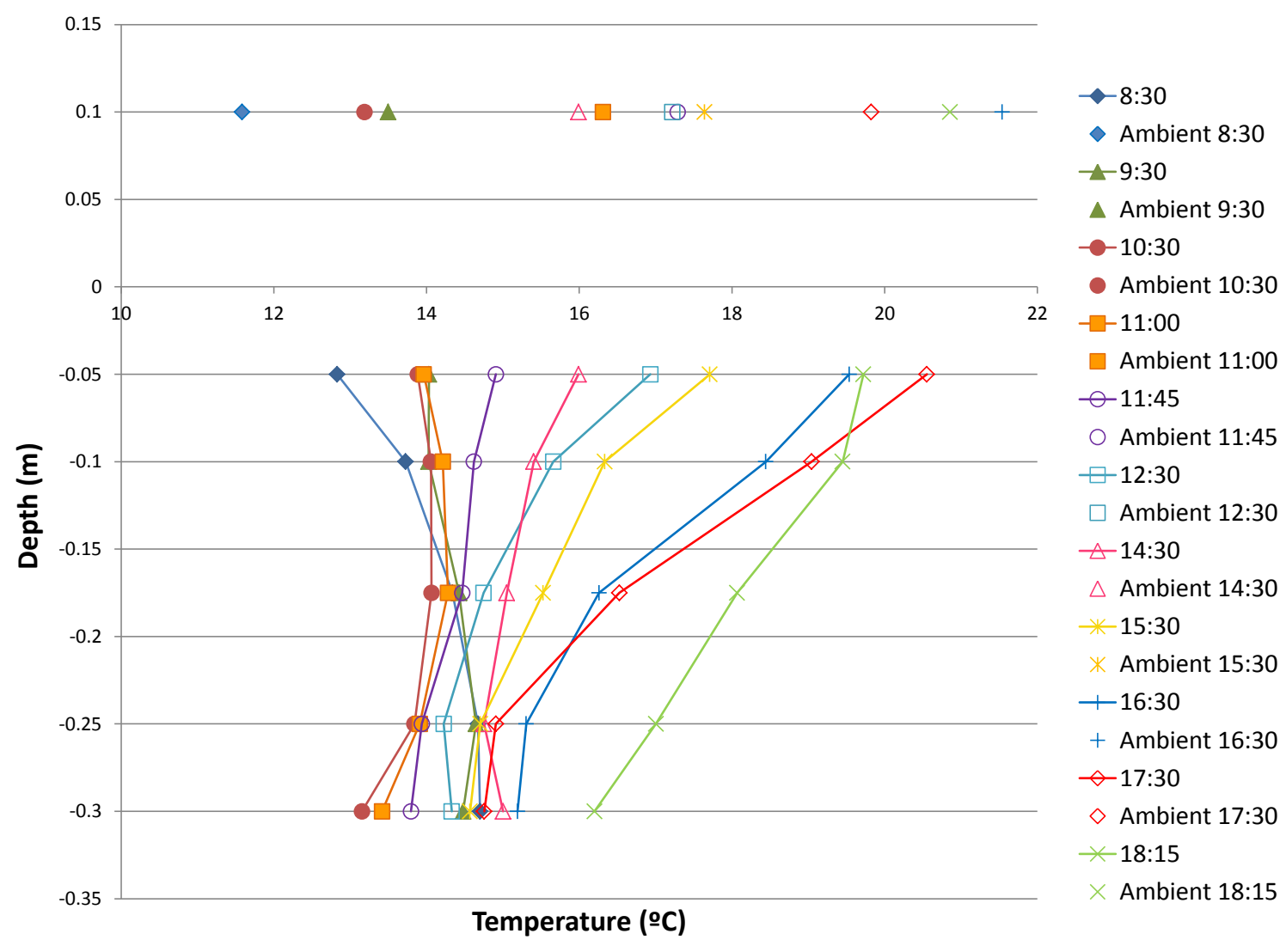

Fig. 14. Internal temperature distribution throughout the day for a $0.32 \mathrm{~m}$ slab without formwork (Sabadell building). 


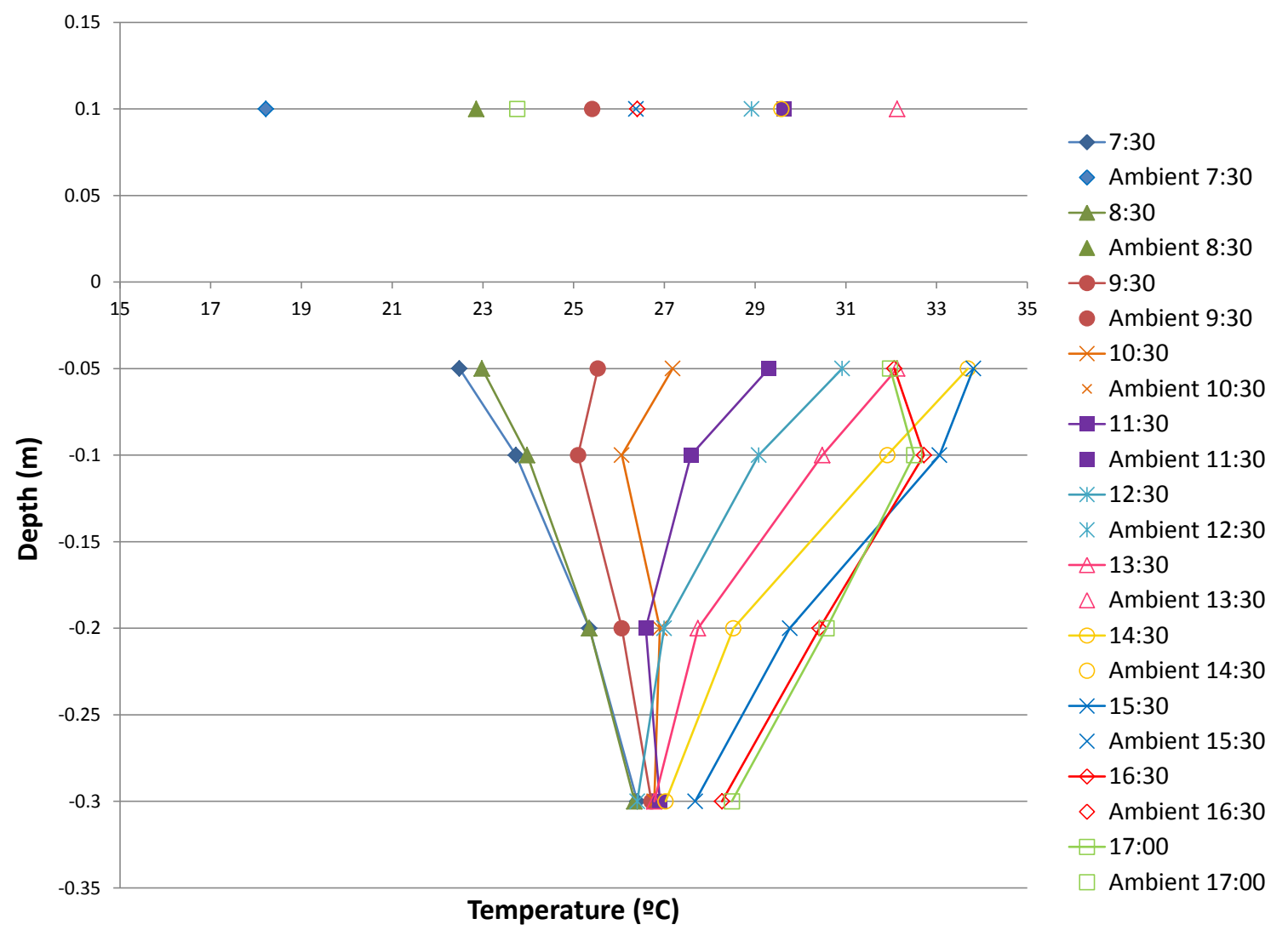

Fig. 15. Internal temperature distribution throughout the day for a $0.40 \mathrm{~m}$ slab supported by formwork

(Valencia building). 


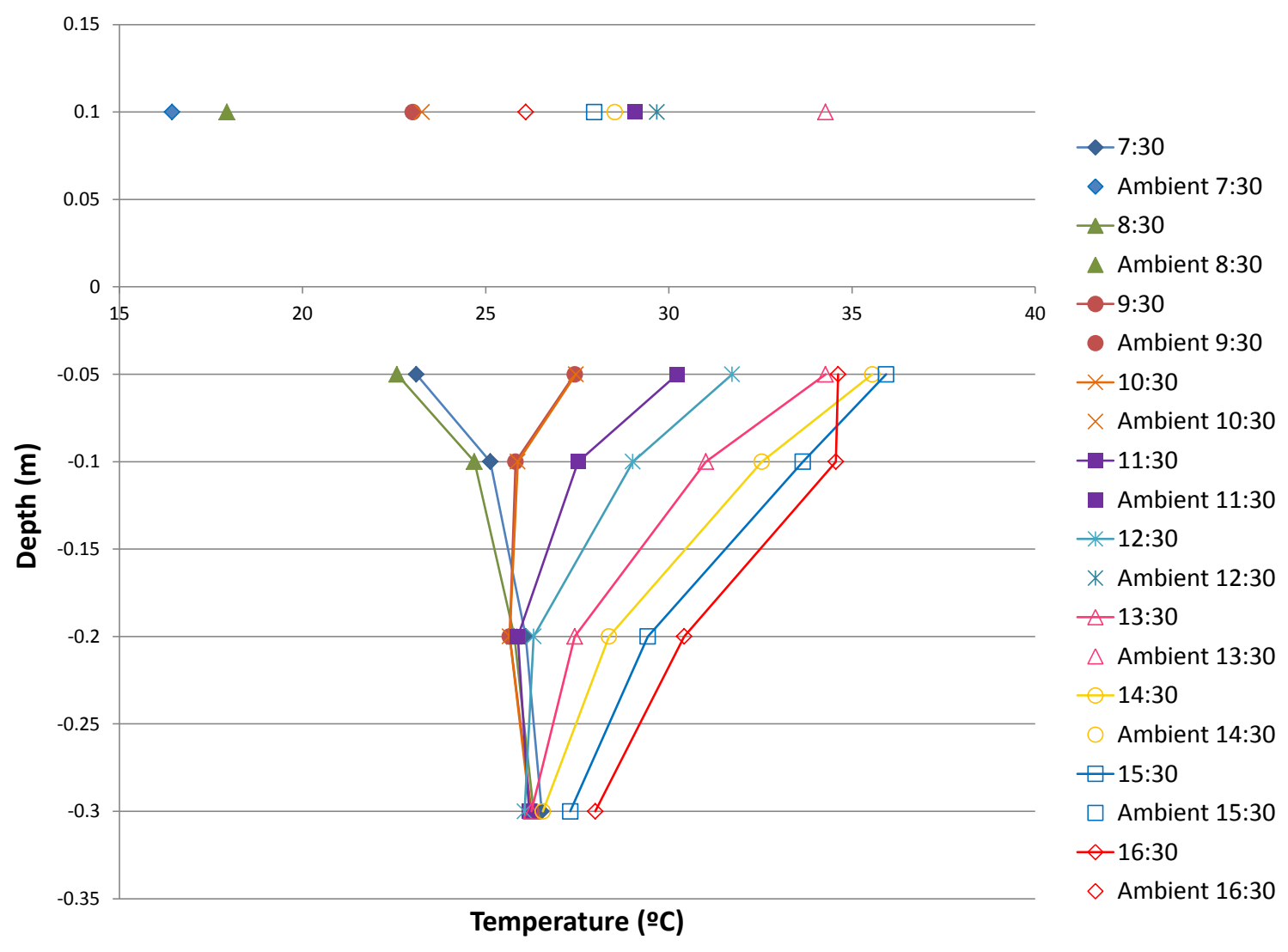

Fig. 16. Internal temperature distribution throughout the day for a $0.40 \mathrm{~m}$ slab without formwork and with direct sunlight (Valencia building). 


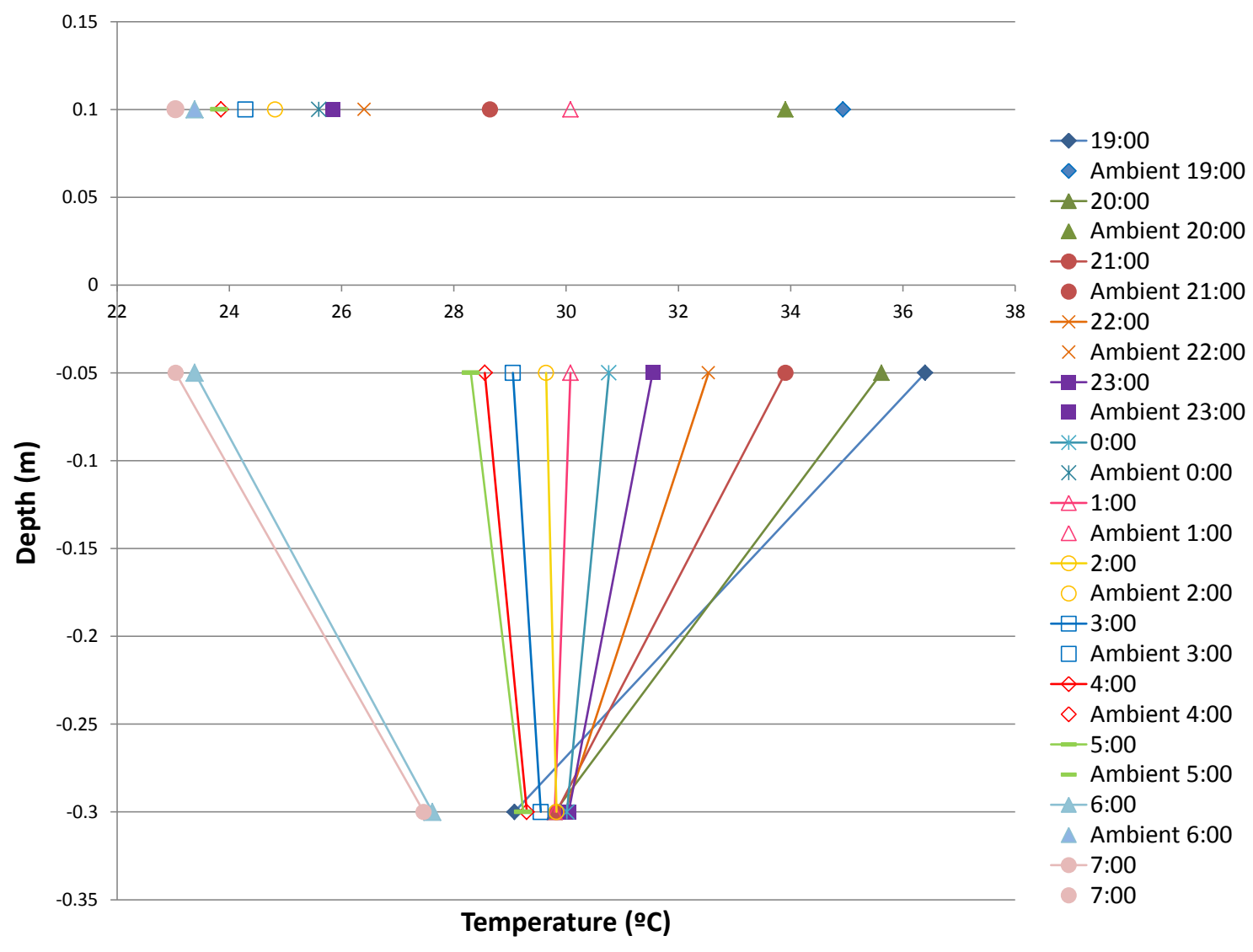

Fig. 17. Internal temperature distribution throughout the day for a $0.40 \mathrm{~m}$ slab without formwork and away from direct sunlight (Valencia building). 

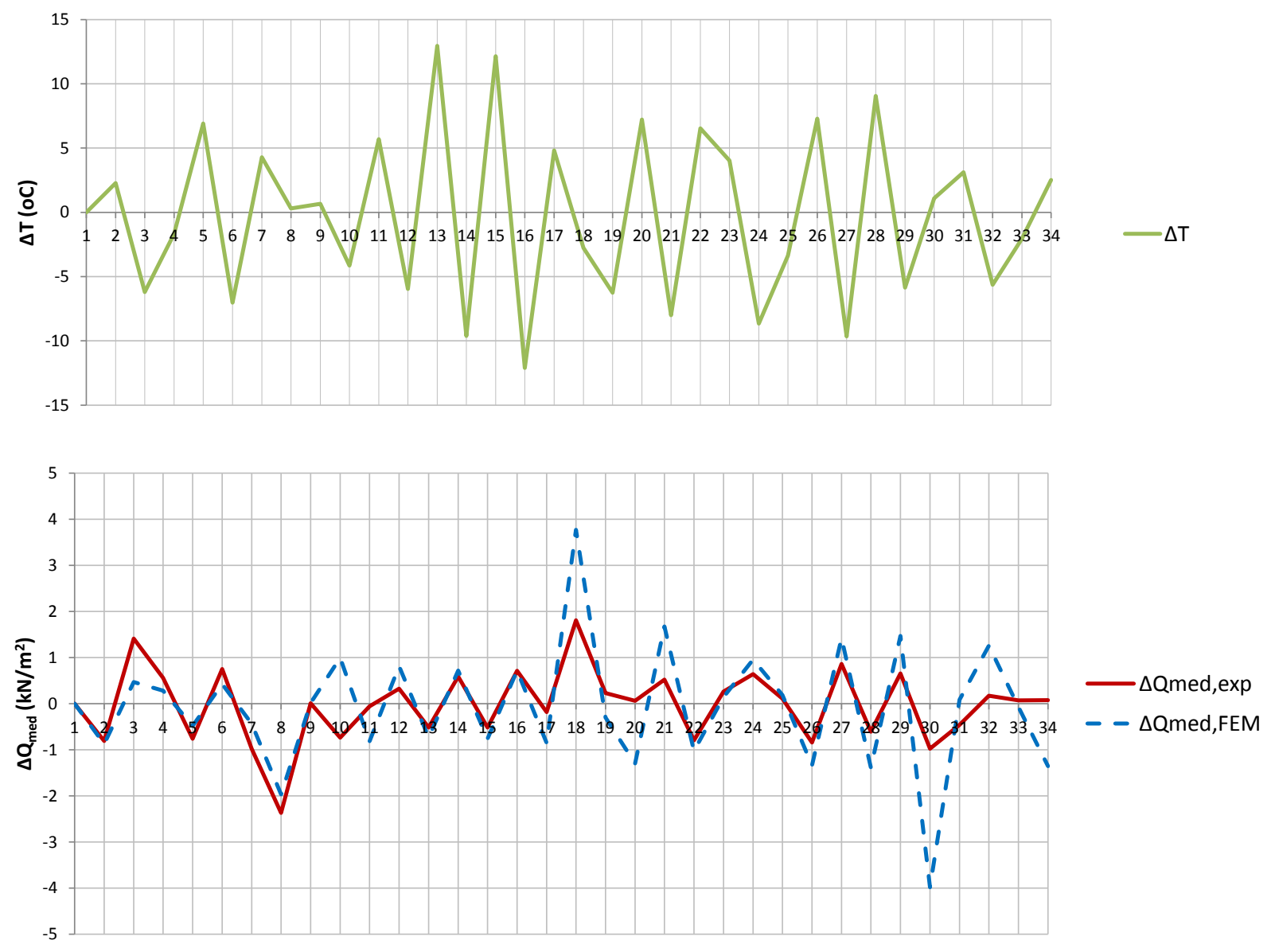

Fig. 18. Increases in temperature and average loads in experimental building and FE model for Slab 1. 

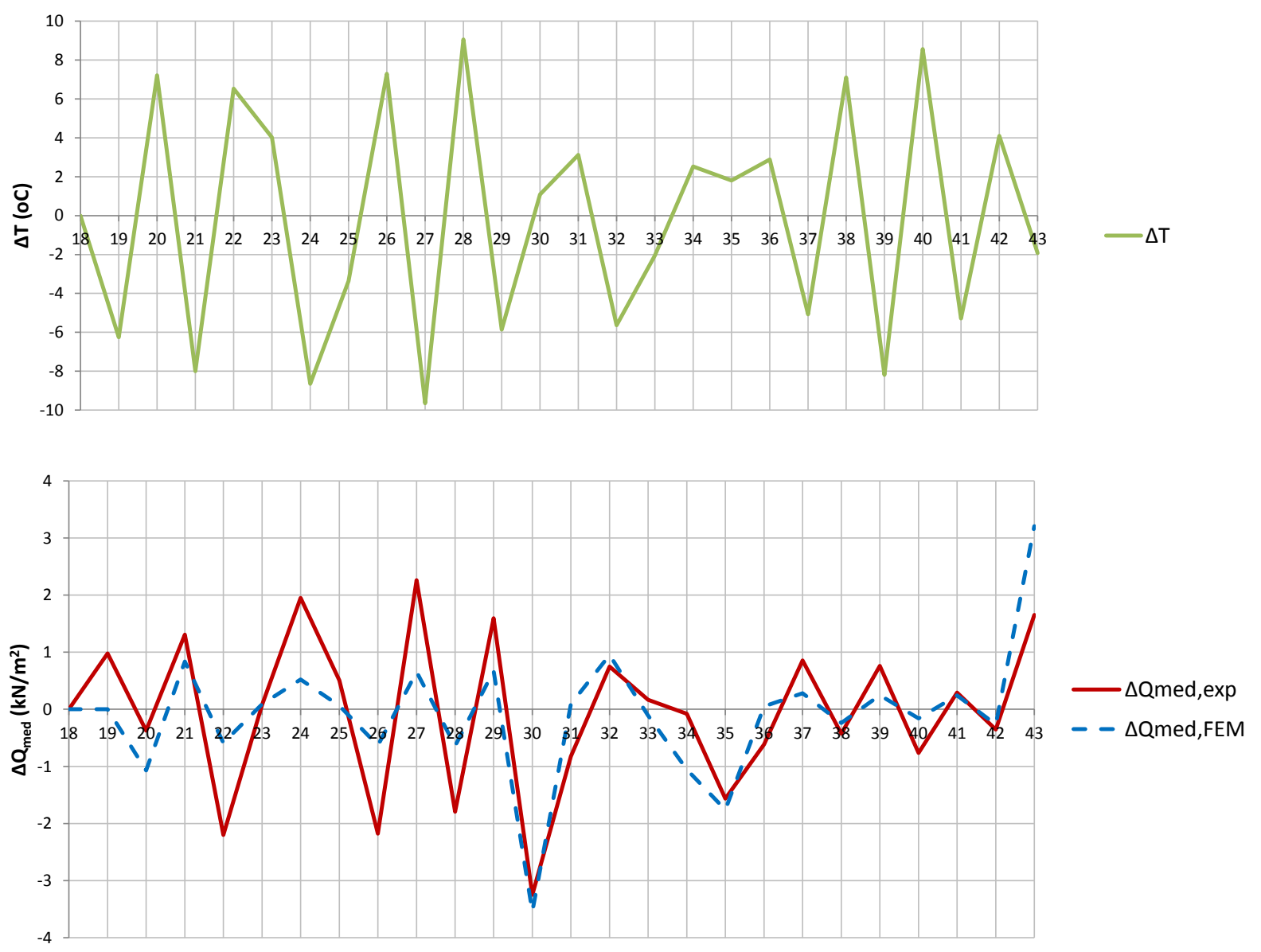

Fig. 19. Increases in temperature and average loads in experimental building and FE model for Slab 2. 


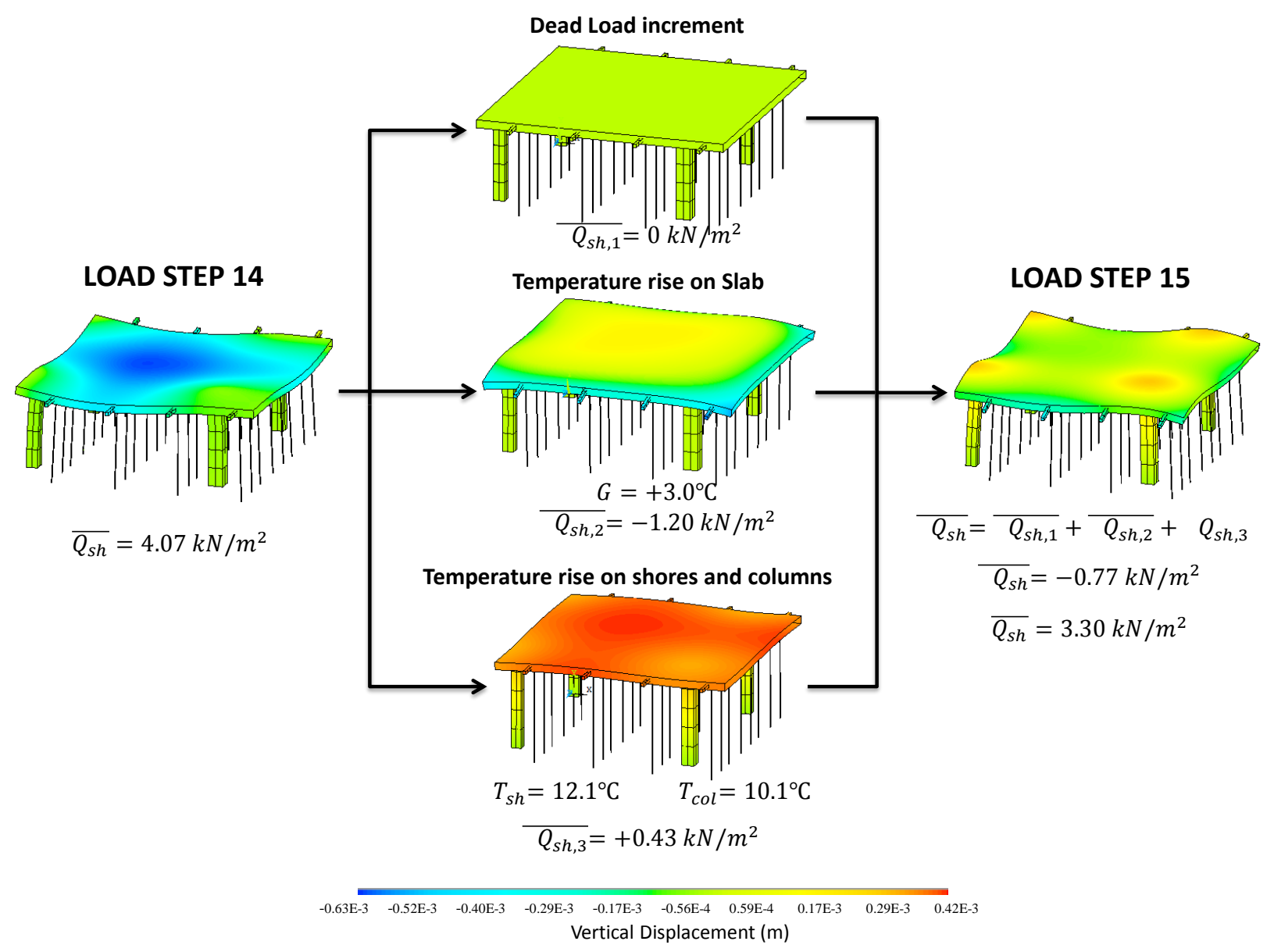

Fig. 20. Slab deflection and load increments on shores due to changes in temperature between load steps 14 and 15 